Discussion Paper No. 10-089

\title{
The National Regulatory Structure Against the Background of the European Regulatory System
}

Tobias Veith

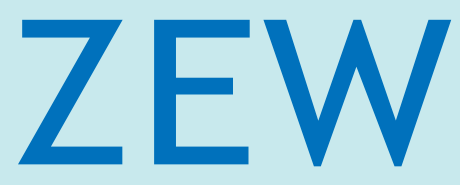

Zentrum für Europäische Wirtschaftsforschung $\mathrm{GmbH}$

Centre for European

Economic Research 
Discussion Paper No. 10-089

\title{
The National Regulatory Structure Against the Background of the European Regulatory System
}

\author{
Tobias Veith
}

Download this ZEW Discussion Paper from our ftp server:

ftp://ftp.zew.de/pub/zew-docs/dp/dp10089.pdf

Die Discussion Papers dienen einer möglichst schnellen Verbreitung von neueren Forschungsarbeiten des ZEW. Die Beiträge liegen in alleiniger Verantwortung der Autoren und stellen nicht notwendigerweise die Meinung des ZEW dar.

Discussion Papers are intended to make results of ZEW research promptly available to other economists in order to encourage discussion and suggestions for revisions. The authors are solely responsible for the contents which do not necessarily represent the opinion of the ZEW. 


\section{Non-technical summary}

The telecommunication sector is influenced by various political powers: The European Parliament, together with the European Commission, fosters the European integration process in network-based markets and uses alternative strategies to align national regulatory systems. National governments support this European integration strategy. However, they follow also national aims which are not necessarily in line with the European integration process. Finally, sub-national governments know of the importance of telecommunications for regional economic development and, therefore, seek to attract (support for) infrastructure investments.

In this paper, I analyze the intermediate role of national governments between panEuropean aims and national and sub-national aims. I first consider pan-European regulation guidelines and instruments to tackle the integration process. One key vehicle in this context are the Regulatory Packages which should provide guidelines during the transition of European telecommunication markets from monopolistic national markets to integrated European-wide competitive markets. National lawmakers transform these guidelines to national laws taking into account national specificities and national regulators control their adoption to markets.

However, national governments have been (and still are) engaged in national telecommunication markets in multiple roles: Former monopolists were under governmental control for a long period of time even after the liberalization and, in many countries, governments still keep the majority of shares today. Meanwhile, governments have a strong impact on strategic regulatory decisions and, finally, see the availability of an adequate telecommunication infrastructure as a major requirement for economic growth. For internalizing the growing positive externalities provided by the availability of telecommunications, public support in infrastructure projects is a key pre-requisite. Comparing the situation across alternative member states shows that the ambiguous roles of governments had a strong impact on the development of competition in telecommunication markets after the liberalization.

Based on early experience shortly after the liberalization, the European Commission seeks to separate the alternative roles of governments from each other. However, the practical implementation is a major challenges even ten years after the liberalization. As the infrastructure is the key input for providing telecommunication services, comprehensive investments require an integrated regulatory approach where incentives to invest and to operate the infrastructure have to be controlled and enforced by regulators with adequate decision powers to support the European integration process. This issue becomes even more relevant when taking into account the importance of telecommunications in the European economic growth process after the financial crisis.

I discuss the role of the government bearing in mind market-oriented competition arguments which mainly demand the separation of the roles of the governments and also more macroeconomic oriented arguments which demand an integrated guidance taking into consideration the key role of telecommunications for other sectors. Finally, I consider the alternative approaches in the light of the latest Regulatory Package which was installed in December 2009 and discuss the role of governments under these new guidelines. 


\section{Das Wichtigste in Kürze}

Der Telekommunikationssektor wird durch unterschiedliche politische Kräfte beeinflusst: Das Europäische Parlament, gemeinsam mit der Europäischen Kommission, verfolgt den europäischen Integrationsprozess in netzbasierten Märkten und wendet unterschiedliche Strategien an, um nationale Regulierungssysteme einander anzugleichen. Nationale Regierungen unterstützen dieses Ziel. Sie verfolgen aber auch nationale Ziele, die nicht notwendigerweise mit dem europäischen Integrationsprozess vereinbar sind. Regionale und kommunale Verwaltungen wissen um die Bedeutung der Telekommunikationsinfrastruktur für ihre regionale ökonomische Entwicklung und fordern daher eine Unterstützung bei Investitionen durch regionale Förderprogramme.

In diesem Papier betrachte ich die Rolle nationaler Regierungen zwischen europäischen, nationalen und regionalen Zielen. Zunächst werden überblickhaft europäische Vorgaben und Instrumente vorgestellt, mit deren Hilfe der Integrationsprozess gelenkt wird. Das zentrale Steuerungsinstrument sind dabei die Regulierungspakete, die Vorgaben für den langfristigen Übergang vormals monopolistischer nationaler Märkte zu einem europaweit integrierten wettbewerblichen Telekommunikationsmarkt bieten. Nationale Gesetzgeber überführen diese Richtlinien in nationale Gesetze unter Berücksichtigung nationaler Besonderheiten und nationale Regulierungsbehörden lenken und kontrollieren die Umsetzung in nationalen Märkten.

Dennoch ist die öffentliche Hand in vielen Ländern auch nach der Liberalisierung noch aktiv in nationalen Märkten in unterschiedlichen Rollen engagiert: Bei früheren Monpolisten sind öffentliche Eigentümer immernoch die Mehrheitseigentümer. Gleichzeitig haben nationale Regierungen einen starken Einfluss auf strategische Regulierungsentscheidungen und verstehen die Bedeutung einer adäquaten Telekommunikationsinfrastruktur als notwendige Voraussetzung für wirtschaftliches Wachstum. Um wachsende positive Externalitäten aufgrund von Telekommunikationsinfrastruktur zu internalisieren, ist eine verstärkt öffentliche Unterstützung beim Infrastrukturausbau eine wesentliche Voraussetzung. Der Vergleich zwischen verschiedenen Ländern zeigt, dass die unterschiedlichen Rollen der öffentlichen Hand einen starken Einfluss auf die Entwicklung des Wettbewerbs in Telekommunikationsmärkten nach der Liberalisierung hatten.

Auf der Grundlage früher Erfahrungen kurz nach der Liberalisierung fordert die Europäische Kommmission eine Separierung der unterschiedlichen staatlichen Rollen. Die praktische Umsetzung ist allerdings eine große Herausforderung auch noch 10 Jahre nach der Liberalisierung. Da die Infrastruktur der Schlüssel für das Angebot von qualitativ hochwertigen Telekommunikationsdiensten ist, erfordern umfangreiche Investitionen einen integrierten Regulierungsansatz, wobei Regulierer mit entsprechender Entscheidungsfähigkeit Anreize zur Investition und zum Betrieb von Infrastrukturen schaffen und fördern sollten. Dies ist insbesondere im Hinblick auf die Schlüsselrolle von Telekommunikation im europäischen Wachstumsprozess nach der Finanzkrise zu bedenken.

Ich vergleiche die unterschiedlichen Rollen der öffentlichen Hand unter Berücksichtigung von Wettbewerbsargumenten, die eine Separierung der Rollen fordern, mit eher makroökonomisch orientierten Argumenten, die eine integrative Lenkung des Telekommunikationssektors als Schlüsselsektor zur Entwicklung anderer Sektoren berücksichtigen. In einem letzten Schritt diskutiere ich die Ergebnisse vor dem Hintergrund der Veränderungen im Rahmen des letzten Regulierungspakets, das im Dezember 2009 eingeführt wurde. 


\title{
The National Regulatory Structure against the Background of the European Regulatory System
}

\author{
Tobias Veith ${ }^{\dagger}$ \\ Centre for European Economic Research (ZEW), Mannheim, Germany
}

\begin{abstract}
States and their representatives, national governments, play a key role in national telecommunication markets. As lawmakers, they determine the playing field of the agents in the markets and the decision powers of national regulators. Simultaneously, they are involved in appointing presidential chambers of national regulators. On the other hand, governments keep shares in regulated companies and support single infrastructure projects based on financial and legal state aid measures. Therefore, European Union regulatory frameworks require a strict separation of tasks between national ministries. However, the European Commission has repeatedly criticized member states for in-transparency and insufficient separations of tasks in national implementation.

While the Second Regulatory Package balanced competition and investment aims, the new Regulatory Package implemented in December 2009 dedicates a higher weight to the role of infrastructure quality as a driver of service innovations. Moreover, national regulators become more independent, and former national regulation tasks are partially shifted to the pan-European level. In consequence, the role of governments also changes.

I discuss the transposition process of Regulatory Packages to national laws and how they have been implemented on the national level to learn more about how the new Regulatory Package will affect the national situation and the European integration process.
\end{abstract}

Keywords telecommunication infrastructure, local loop competition, regulatory independence

JEL Classification K 23, L 13, L 43, L 96

†ZEW, P.O. Box 103443, 68034 Mannheim, Germany. Phone: +49 621 1235-296, Fax: +49 621 1235-

170. E-mail: veith@zew.de

I'm grateful for financial support from the Deutsche Telekom AG. 


\section{Introduction}

Multiple political powers affect regulation and, thus, the development of telecommunications on the European level, the national level and the sub-national level. The EU Parliament and the EC seek to reach the objective of a pan-European integration of member states' telecommunication markets and provide the necessary regulatory instruments on both the European and the national level. National governments support this aim but are additionally interested in not losing national sovereignty. Moreover, national governments follow aims, which are not primarily in line with the integration process but which have to address individual member states' goals and which have to tackle individual member states' challenges. Due to the key role of telecommunications for economic development, national governments are comprehensively engaged in their national telecommunication sectors in alternative roles. In this paper, I consider these roles of national governments under the European regulatory framework with a particular focus on the implementation of the first two Regulatory Packages ${ }^{1}$ and how they affect the development of national telecommunication markets. ${ }^{2}$

A number of studies exist which address the role of the government in particular industries. Seminal papers are the contributions by Stigler (1971) and Peltzman (1976) or, more recently, Henisz and Zelner (2001). Persson and Tabellini (2000) and, subsequently, Duso and Röller (2003) consider the political influence in the context of (de-)regulation. While most studies analyze the role of the government in the economy or in regulated sectors as a whole, the telecommunication sector provides a particular situation, firstly, because of its key role as an input good for other industries and, secondly, because of its historical background as a fully governmental controlled sector, which has been liberalized. This background caused strong interrelationships between national governments as well as public administrations and incumbent operators and led to personal interdependencies between market participants and governments or between regulators and governments. The strong interrelationships between political powers and telecommunication sectors are under the suspicion of the EC as they might influence competition and the European integration process.

\footnotetext{
${ }^{1}$ These are the Regulatory Package of 1998 in line with the liberalization and the Regulatory Package of $2002 / 2003$ for the harmonization of national telecommunication markets preparing the integration process.

${ }^{2}$ I concentrate on the governmental influence on the sector and, to a far extent, refrain from the reverse influence where this is possible.
} 
Concerning network-based markets an ongoing debate exists among academics, politicians and infrastructure and service providers about the compatibility of long-run investments with a sunk-cost character and competition on the infrastructure or, also, between alternative infrastructures. The key regulatory challenge is the provision of adequate investment incentives when competition keeps profits low. Against this background, Section 2 provides an overview of the European regulatory system with its instruments and how they are implemented to balance these static and dynamic regulation aims. Moreover, I describe the discussion of competition promotion and infrastructure investments based on the existing European regulatory system.

Section 3 considers the alternative roles of governments as the representatives of states in the telecommunication sector. As lawmakers, governments determine the framework for the development of the sector as a whole. Simultaneously, governments affect strategic decisions of regulators as, in general, national parliaments elect the members of the regulators' presidential chambers, i.e. the strategic departments of regulators. On the other hand, governments are involved in sector participants and directly influence sector activities as, in most countries, they still keep minority stakes in telecommunication operators and support the installation of infrastructure with public grants. Combining the measures available in the alternative roles even increases regulatory powers to affect sector activities and to control the sector as a whole. I use examples from the EC Implementation Reports to consider the dichotomous roles of governments in the interplay of investments, competition and regulation and compare the national outcomes.

Section 4 is an extension to the previous sections as it discusses main regulatory changes of the Third Regulatory Package, which has to be adopted to national laws by June 2011, in the light of the current market situation. Thus, Section 4 provides an outlook of expected future developments based on the current momentum in the European market integration process. Section 5 concludes the paper and highlights some key aspects which require further consideration also under the Third Regulatory Package. 


\section{Regulation - the pan-European Perspective}

This section provides an overview of European regulatory instruments mainly from the EC perspective and, subsequently, discusses the double aim of competition enforcement and investments in the context of the First and the Second Regulatory Package.

\subsection{Instruments for Harmonizing Regulation in Europe}

\subsubsection{Regulatory Packages}

The EC intends to merge individual telecommunication markets of EU member states to one common EU-wide market and uses both ex ante and ex post measures to implement this comprehensive task. The key pre-requisite is the harmonization of national telecommunication laws. Regulatory Packages determine the framework of regulation harmonization as they provide the guidelines to be implemented to national laws in all member states. Until today, two EC Regulatory Packages are effective. The first was established in line with the liberalization in 1998 as a framework for the transition of former monopolistic markets to efficient and competitive markets. The second was introduced in 2002/2003 to continue the harmonization of national telecommunications and to foster and to secure competition aims. Following the first proposal for this Second Regulatory Package, it became necessary to introduce new rules, which meet the unexpected technological and structural changes after liberalization. ${ }^{3}$

Each Regulatory Package covers a range of multiple guidelines ordered in directives which give more detailed information about how regulation should be implemented on the national level. For example, the Second Regulatory Package consists of the Framework Directive, which provides the general framework for the implementation of regulation, and five specific directives, which all cover a particular issue in national markets. ${ }^{4} \mathrm{Mem}-$ ber states are obliged to transpose these directives to national laws in a pre-determined period of time taking into account country distinctions.

Due to the growing importance of customers as active information providers, the Third Regulatory Package stronger secures the new role of customers fostering the pan-

\footnotetext{
${ }^{3}$ http://ec.europa.eu/information_society/topics/telecoms/regulatory/new_rf/ documents/com2000-393en.pdf

${ }^{4}$ The five specific directives are the Access Directive (2002/19/EC), the Authorization Directive (2002/20/EC), the Universal Directive (2002/22/EC), the Directive on Privacy and Electronic Communications (2002/58/EC) and the Directive on Competition in the Markets for Electronic Communications Networks and Services (2002/77/EC). Please also see Figure 5 in Appendix .
} 
European integration of telecommunication markets. This last Regulatory Package was set up after the second round of market reviews in 2006, was introduced in December 2009 and has to be transposed to national laws by June 2011.

\subsubsection{Monitoring and Controlling the Integration Process}

While Regulatory Packages provide the strategic perspective for harmonizing European regulation efforts, the EC uses alternative measures and institutions to smooth the longterm regulatory process and to react on current issues. In particular, it demands a vivid exchange of information based on public consultations with interested groups before adopting new regulatory steps or adjusting current regulations. Considering the monitoring procedure, NRAs are obliged to analyze markets on a regular basis and consider whether companies with SMP exist. The results of these analyses are reported to the EC (Framework Directive, article 16). This individual market information offers a comprehensive knowledge stock about national markets as a whole, individual companies with SMP and also NRAs, national laws and particular aspects of national regulation habits. Based on this information and on own monitoring results, the EC directly intervenes in telecommunication markets if it suspects the situation in a market not to be in line with the EU regulatory framework.

The EC uses mainly three types of instruments to intervene on current regulatory issues depending on the addressee: Firstly, the most comprehensive intervention refers to a particular market type across all member states. It is adopted if the EC expects Regulatory Packages not to meet a particular issue, due to changes in the market structure or due to technological changes (cross-market interventions). Secondly, the EC addresses a member state market if it suspects national regulation to be insufficient or if current or forthcoming regulatory practices benefit one company over its competitors (countryaddressing interventions). An example, which will be discussed below, is the roll-out of high-speed internet in Germany. Thirdly, the last type of interventions addresses single companies or a group of companies if SMP is abused (company-specific interventions). While the first two types require reactions by national institutions, the government or the regulator, the last type directly addresses individual companies and, thus, comprises the gray area between regulation and antitrust. ${ }^{5}$

Alternative approaches in line with the harmonization and integration of European telecommunication markets offer a comprehensive set of instruments for the regulation

\footnotetext{
${ }^{5}$ More detailed information about the alternative instruments of the EC and how their execution affects markets and companies is provided in Veith (2010b).
} 
process which are primarily based on a top-down approach due to the coordination of the European integration process (the Regulatory Packages, the monitoring procedures). On the other hand, reverse loops are installed providing input to the EC (consultations with NRAs and other interested groups). Moreover, national distinctions are explicitly recognized in the transposition process of Regulatory Packages to national laws. With this combination of reverse monitoring and controlling mechanisms, the integration process allows for comprehensive sovereignty of national member states. However, national governments use their sovereignty to follow own aims with national telecommunication sectors, which are not necessarily in line with the pan-European integration aim as will be discussed in Section 3.

\subsection{Investments and Competition}

Telecommunications experienced a comprehensive technological change in transmission technologies between the late 1990s and about 2004. Radical technological innovations enable much higher transmission rates, which allow for higher-quality services on the existing infrastructure. ${ }^{6}$ Although improvements in the transmission technology encourage higher-quality services, the majority of the existent physical infrastructure components remain on their basic level. In consequence, an increasing gap between physical infrastructure development and the transmission technology development exacerbates the internalization of service profits by physical infrastructure operators.

Service providers take up the potential of higher transmission capacities, firstly, by providing more services and, secondly, by providing higher-quality services. This differentiation on the service level increases the attractiveness of telecommunication usage as a whole. As a result, transmission system innovations moves telecommunication markets from a "supply push" situation to a "demand pull" situation. ${ }^{7}$

However, the introduction and protection of efficiency and competition is an ongoing challenge within the European integration process. After competition has been installed on the service level, the cumbersome task to be solved is local loop competition, which requires NRAs' and competition authorities' attention until today. As infrastructure providers bear the risk of (not) re-financing investments, they choose the level of

\footnotetext{
${ }^{6}$ Think of, e.g., ADSL, which requires physical adjustments in the street cabinets to enable higher speed services like, e.g., VoIP services (De Bijl and Peitz, 2005).

${ }^{7}$ The impact of service competition on infrastructure provision is considered in Veith (2010a) in more detail.
} 
infrastructure availability based on company-specific strategic aims but ignore positive externalities provided by their investments. Following Knieps (2007) and Bauer and Bohlin (2007), national telecommunication laws must strictly determine the environment for efficient local loop access negotiations. Consensus exists among politicians, NRAs and telecommunication companies on the essential facility property of the local loop. However, the guidelines in the Second Regulatory Package leave room for interpretation resulting in additional challenges in the national transposition process. As the Regulatory Packages provide no further details on how to implement directives to national laws, lawmakers on the national level have repeatedly chosen an insufficient level of concreteness in the transposition process.

In a nutshell, the EC follows the aim of telecommunication market integration across all EU member states with alternative instruments, which include directed and indirected interventions and ex ante and ex post monitoring and controlling instruments. Regulatory Packages are the key vehicle as they prepare the steps to the integration and guide the comprehensive preparations. The rules provided in this framework have to be transposed to national laws by national governments taking into account national distinctions. As EU member states are at different stages of market competition and infrastructure availability and quality, the guidelines are set at a very high level of abstraction. This provides a particular challenge for NRAs' implementation to markets as national transpositions of highly abstractive guidelines also result in a low level of concreteness in many national telecommunication laws. Moreover, insufficient transposition and in-transparent decision-making on the national stage hamper both competition and, in particular, investments in many EU member states.

\section{The Dichotomous Roles of Governments in the Telecommunication Sector}

Due to the high impact of telecommunications on other sectors, national governments follow multiple dichotomous aims in telecommunication markets. These aims are the transposition of the EU guidelines as well as the installation of a sufficiently high level of infrastructure and service quality and the installation of competition and efficiency. However, they also comprise individual national aims, which directly and indirectly affect 
the transposition process. Until today, most EU member states are actively engaged in their telecommunication sectors by keeping shares and stakes in the incumbent operator and by providing legal and financial incentives for infrastructure investments. Following Levy and Spiller (1994, 1996), institutional endowments of countries in a sector influence the implementation of regulatory rules and directly affect the strategic behavior of regulated companies.

Turning to the link between infrastructure provision and users, governments use their interrelationship to sector companies to support the installation of adequate infrastructure quality and availability. Based on the Universal Service Directive and the Framework Directive (2002/21/EC, Article 8.2), national governments have to balance the roll-out of high quality infrastructure in more profitable regions and the availability of an adequate level of infrastructure quality in less profitable regions. Thus, they have to keep the urban-rural quality differential as low as possible. While this is of minor importance for smaller countries such as the Netherlands, it is a major problem for larger countries with a lower population concentration such as France or Germany. In densely populated areas, companies voluntarily invest as they expect to re-finance their investments in a shorter period of time. In contrast, infrastructure providers are less interested in investing in less densely populated areas because of a lower return-on-investments ratio. Therefore, investments in rural areas are enforced by universal service obligations and public funding to guarantee a basic level of infrastructure capacity. In the following, I consider alternative roles with which governments influence telecommunication competition and investments, how they are implemented and how they interact.

\subsection{Governments as Lawmakers and Providers of the National Regulatory System}

Governments have to develop and maintain a legal system, which adopts the alternative propositions on infrastructure provision and competition derived from the Regulatory Packages. On the one hand, such a system determines the framework for the current market situation and, on the other hand, it has to be flexible for adjustments in the market structure and in technological developments. Thus, such a framework has to balance static and dynamic regulation aims depending on the underlying intention of governments. The EC is aware of these challenges for national policymakers in the 
transposition process and allows for flexibility, firstly, with regard to adjustments to national distinctions, secondly, in terms of transposition time and, thirdly, due to the concreteness and wording of national laws.

National distinctions comprise geographical and demographical as well as cultural differences and distinctions in national administrative systems. While geographical and demographical aspects are observable and could easily be monitored by European administrations, cultural distinctions and, in particular, aspects depending on national administrative systems are not fix requisites but could mostly be adjusted only with a long-term perspective. This is a key challenge in the telecommunication sector: The administrative system is strongly based on the sector structure before the liberalization with one publicly owned telecommunication provider and a low level of technological change. However, this system hardly meets the market development after the introduction of competition, which hampers the position of competitors due to lagging regulatory flexibility.

The transposition time is the time span between the introduction of a new Regulatory Package and the finalization of its implementation to the national law. While the Regulatory Package determines a final date for the transposition, this requirement provokes criticisms by the EC as national governments have intentionally extended the transposition process. In particular, when transposing the First Regulatory Package, many countries needed more time than the pre-determined period. In less innovative industries, an extension of the implementation time shifts upcoming competition to the future. However, in the telecommunication sector, the extension of the first transposition period came together with the implementation of more comprehensive transmission technologies in fix-line markets (broadband for private customers). Thus, the extension of the transposition period enabled incumbent operators to establish their customer base with no or only little competition, which provided an increasing first-mover advantage. Based on long-lasting contracts, customers were locked in with their providers. Consequently, even the EC requirement of local loop unbundling in 2000 (Regulation No. $2887 / 2000 /$ EC) has had only a weak effect on competition.

Turning to the third aspect, due to their long-term perspective, infrastructure investments require non-ambiguous legal rules and a highly transparent regulation pattern, which enable investors to foresee future steps of major adjustments in telecommunication laws. A less concrete level of national law wording offers room for interpretation driving the workload of national and European courts. Therefore, both incumbent and 
Table 1: National Lawmaking against the Background of the EU Regulatory Guidelines

\begin{tabular}{|c|c|c|}
\hline Year & Country & Statement/Concern \\
\hline \multirow[t]{2}{*}{1997} & UK & Main principles of the first regulatory package became effective. \\
\hline & UK & $\begin{array}{l}\text { Authorities have hampered local loop access for competitors arguing that the access to the copper } \\
\text { loop would not improve local loop competition. In contrast, such a step would jeopardize the } \\
\text { development of facility-based competition. }\end{array}$ \\
\hline 1998 & Germany & $\begin{array}{l}\text { The incumbent was required to offer unbundled local loop access but only for fully unbundled raw } \\
\text { copper lines. }\end{array}$ \\
\hline 1999 & Sweden & $\begin{array}{l}\text { The Swedish regulator PTS proposed an amendment to the national Telecommunications Act which } \\
\text { enables PTS to unbundle the local loop through licensing conditions. }\end{array}$ \\
\hline $\begin{array}{l}\text { before } \\
2000\end{array}$ & $\begin{array}{l}\text { Nether- } \\
\text { lands }\end{array}$ & $\begin{array}{l}\text { Main Distribution Frame (MDF) access was considered to be a form of special access what } \\
\text { contradicted the habits in other countries. }\end{array}$ \\
\hline 2000 & France & $\begin{array}{l}\text { Competitors argued that shortcomings in the administrative power of the regulator hamper upcoming } \\
\text { competition on the local loop. Moreover, disputes about ADSL provision would have resulted in a } \\
\text { barrier to competition, this particularly affects the entry of smaller and medium competitors. In their } \\
\text { perspective, public authorities failed to act decisively on the behavior of the incumbent. In } \\
\text { consequence, the incumbent operator was able to expand his strong and even dominant position in } \\
\text { the broadband market. }\end{array}$ \\
\hline \multirow[t]{3}{*}{2001} & France & $\begin{array}{l}\text { The EC points out decisive delays in the implementation of local loop competition and the access to } \\
\text { collocation sites what would be mainly due to the absence of clear and effective enforcement } \\
\text { procedures. }\end{array}$ \\
\hline & $\begin{array}{l}\text { Nether- } \\
\text { lands }\end{array}$ & $\begin{array}{l}\text { From } 31 \text { December } 2000 \text { until mid September 2001, in the crucial time period of local loop } \\
\text { unbundling and ADSL roll-out of the incumbent, OPTA was appointed as the Dutch regulator but } \\
\text { was not designated as the NRA in charge of executing EC regulation what led to significant delays in } \\
\text { the introduction of full unbundled local loop accesses in the Netherlands. }\end{array}$ \\
\hline & Sweden & $\begin{array}{l}\text { The Swedish Telecommunications Act does not provide the powers to the NRA to demand for the } \\
\text { introduction of flatrate internet access call origination (FRIACO) which is found to be a central } \\
\text { requisite for retail competition in other countries. }\end{array}$ \\
\hline \multirow[t]{2}{*}{2004} & Germany & $\begin{array}{l}\text { The German Telecommunications Acts categorizes market squeezing as an abusive strategy. } \\
\text { However, the EC doubtfully raises concerns given potentially positive effects on competition. A } \\
\text { corresponding resale obligation is also limited until } 30 \text { June } 2008 \text { and covers only the resale of } \\
\text { access services which is bundled with other services. }\end{array}$ \\
\hline & $\begin{array}{c}\text { Nether- } \\
\text { lands }\end{array}$ & $\begin{array}{l}\text { The attempt to impose a bitstream access obligation on the fixed-line incumbent operator has been } \\
\text { annulled in the court of justice as the obligation could not be derived from the relevant applicable } \\
\text { legislation. }\end{array}$ \\
\hline
\end{tabular}

Source: Information taken from the respective EC Implementation reports $(1998,1999,2000,2001$, 2004, 2005).

entrant infrastructure providers demand a high level of concreteness in law wordings. Examples, which concern these issues are provided in Table 1. Let us shortly consider the case of local loop unbundling in Sweden as it comprises all three aspects: While 95 percent of Swedish households had access to multiple networks already in 1999 (which mainly comprises fix-line and mobile access), local loop competition was suspected by the Swedish regulator PTS to be insufficient at the time. Therefore, it proposed amendments to the telecommunication law forcing vertically integrated providers with SMP to let competitors into their markets on a cost-based access price. As the Swedish 
government suspected the proposal of PTS to infringe the Swedish constitution, the process of law adjustments delayed local loop access regulation until 2004. Meanwhile, from 31 December 2000 onwards, EU regulation required operators with SMP in the local loop to provide offers for access to competitors. In consequence, the Swedish incumbent voluntarily opened the local loop for competitors but it chose access prices which were in-competitively high as explained by entrant candidates. Turning to the challenge of lawmaking, the inflexible administrative system caused an insufficient implementation of legal rules providing a significant first-mover advantage to the incumbent. This affected local loop competition for a comprehensive period of time even after the adjustment of the law.

\subsection{NRAs: From Ministry Departments to (In)Dependent Public Institutions}

The WTO (1996) describes an independent regulator as a regulator being "separate from, and not accountable to, any supplier of basic telecommunications services". ${ }^{8}$ While this definition relies on the direct interrelationship of the regulator and the regulated market, the EU regulatory approach extends this definition to the interrelationship of regulated companies and political authorities (Article 3 of the Framework Directive). Moreover, the Framework Directive and the Universal Service Directive require NRAs to control and support users' security interests. The stricter separation of companies and the national administrative system and the simultaneous support of users' rights overweight the demand side in the European regulatory system.

Independence of NRAs is legally guaranteed by allocating the administration of shares of telecommunication companies and ownership tasks in different departments than the super-ordinated ministry of the NRA. However, the EC repeatedly raised concerns about the actual implementation of such a separation during the first years after the liberalization and still worries about separation in some member states such as France and, most recently, the Czech Republic (Implementation Report 2008). One key point of criticism is that NRAs are officially separated from governmental authorities in most countries but are accountable to the parliament or other super-ordinated political powers, which determine the legal definitions of NRAs' decision space or budget constraints.

\footnotetext{
${ }^{8}$ http://www.wto.org/english/news_e/pres97_e/refpap-e.htm
} 
Most NRAs are historically derived from former ministries and adherent public administrations. In consequence, NRAs have adopted personnel and employment structures from their predecessors both for strategic and lower hierarchy units. In most countries, the members of the presidential chamber are elected by national parliaments, nominated by the national president or the ministers in charge. Thus, the members of the presidential chambers have proven consistency with the political parties of their electors before their election. ${ }^{9}$ Considering lower hierarchies, NRAs compete with regulated companies for high-skilled employees on the job market. However, as in most EU member states, NRA employees are civil servants, more comprehensive incentives such as higher salaries and a broader perspective of personal development and flexibility make companies much more attractive for job market candidates (ECTA Regulatory Scorecard 2008, executive summary). ${ }^{10}$ In many member states such as the UK or the Netherlands, this job market competition between NRAs and regulated companies led to comprehensive turnovers of NRA personnel after the liberalization and resulted in understaffed NRA departments for multiple years. While regulators, such as OFTEL/OFCOM, are aware of the challenge, they can hardly intervene due to requirements of national lawmakers(Implementation Reports 2000, 2001). Moreover, NRA employees were (and still are) poached by regulated companies, which, firstly, hampers the creation of specific expertise and, secondly, leads to a migration of the existing knowledge stock from NRAs. Deficits in human resource management and, as a consequence, knowledge management hamper the implementation of sustaining regulatory policies.

Additional problems are directly derived from the weakness of human resource management: New entrants complain about the very short-term oriented regulation focus. Following their view arguments, NRAs mainly consider single market aspects but ignore more urgent, broader challenges leading to delays of market developments and providing uncertainty. In particular, new entrants and the EC raised concerns that inefficiencies of NRAs enable incumbent providers to stabilize or even increase their market power. Examples on resulting challenges in local loop competition and investments comprise negotiation time rulings and penalties in the context of local loop access (Germany, 2000), ADSL wholesale pricing (Germany, 2001) or the lack of regulatory interventions in line with incumbents' aggressive pricing mechanisms (Sweden, 2001, and France, 2004).

\footnotetext{
${ }^{9}$ See the discussion in the Special Opinion ('Sondergutachten') 2003 and 2009 , two monitoring reports of the German Monopolies Commission.

${ }^{10}$ The ECTA (European Competitive Telecommunications Association) supports regulation activities in the interest of entrants to telecommunication markets.
} 
As most European NRAs are derived from former ministries or subordinated government agencies, they keep their previous organizational structure. While this structure met the requirements of monopolistic markets with low technological deployments and a constant market structure, problems occur with the transition to more dynamic markets with ongoing comprehensive technological developments. Even today, the EC expresses concerns about the efficiency of developing decision processes in NRAs and argues that the lack of timely and pro-active decisions creates barriers to competition and investments. Following the EC argumentation, inflexibility within the organizational structure of NRAs hampers the transition process and the installation of innovative markets. Some NRAs, in cooperation with their governments, have taken up the criticisms and restructured the internal organization to become more market-oriented as done in the Netherlands or Sweden. Other approaches, such as the UK example, also include the integration of telecommunication-related antitrust tasks and market controls into the scope of NRAs' duties. ${ }^{11}$ These reorganizations prove department boundaries to become much more permeable for personnel qualified in particular fields of relevance and allow the creation of a flexible, project-oriented knowledge stock within NRAs not fixed to individual employees. Reorganization with the focus on market-orientation made OFCOM a commonly acknowledged group of highly skilled experts who consult the British government as well as the EC in line with regulation and investment decisions.

In consequence, the UK example is repeatedly considered as a benchmark for other NRAs: ECTA recommends that NRAs in other EU member states should receive even more complex regulatory powers including also the possibility of functional separation of regulated companies or decision rights on fining abusive companies based on their turnover. ${ }^{12}$ After the functional separation of BT and its local loop unit Openreach in the UK, other NRAs, such as OPTA and PTS, also analyzed whether this approach could be transposed to their countries. However, they refrained from giving a recommendation to their governments due to strong differences to the UK situation. Whether a NRA should be equipped with antitrust instruments to stimulate the double-aim of downstream competition and high-quality infrastructure investments is criticized in the economic literature. In particular, Cave (2006b) and Whalley and Curwen (2008) argue that functional separation within the British incumbent did not have the expected

\footnotetext{
${ }^{11}$ This increase in regulator's powers goes in hand with a reduction of antitrust authorities' competencies.

${ }^{12}$ See the ECTA Regulatory Scorecard (2008).
} 
success as the complexity of the task would be too comprehensive for OFCOM with its current personnel and its financial constraints.

Much more attention is paid to the opposite position for NRAs as the Implementation Reports give multiple examples for an insufficient decision space of NRAs. Concerning the interconnection of alternative infrastructures and the access of service providers to the local loop, the French regulator ART was able to intervene in negotiations only if one company formally requested its support or after negotiations have demonstrably failed. New entrants argued that this approach significantly delays upcoming competition. However, even after legal adjustments for increasing ART's powers in 2001, the regulator did not modify its rules of procedures. In consequence, the incumbent France Telecom regularly questioned the decisions of the regulator bringing cases to courts. As long as court decisions are pending, this hampers competition-increasing actions by market participants and delays infrastructure investments due to missing legal certainty. Based on this and other examples, the EC suspects incumbents strategically to extend the process of the implementation of regulatory steps by challenging NRAs' decisions, as they know of the high workload of national courts. Such examples provide evidence that, besides lawmaking, also organizational and functional slack within regulatory agencies cause legal uncertainty and, thus, reluctance in investments.

In a nutshell, national governments comprehensively affect the strategic orientation of regulators: Firstly, they elect the members of the presidential chambers and, as lawmakers, determine the decision space of regulators. Secondly, they also indirectly influence the efficiency of NRAs by providing the status and incentive scheme for hiring NRA employees. While NRAs' organizational structures are derived from the predecessor organizations, they are not willing to adjust internal structures, which could provide a more case-based structure and, thus, accelerate regulatory decisions providing investment security. A magnitude of examples in the Implementation Reports show that these short-comings also influence national market developments and also the European integration process.

\subsection{The Government and the Incumbent - Infrastructure Provision}

Turning from the legal system and the situation of regulators to the markets, we find most governments to be minority stake-holders in national telecommunication incumbents 
even ten years after the beginning of privatization. Figure 1 displays that only the UK and, finally, the Netherlands have completely withdrawn their involvement. In contrast, in other EU-15 countries, public ownership shares were still above 25 percent in 2007. This raises the question of governments' intentions with minority stakes in former monopolists.

Figure 1: Public Ownership Share in the Incumbent

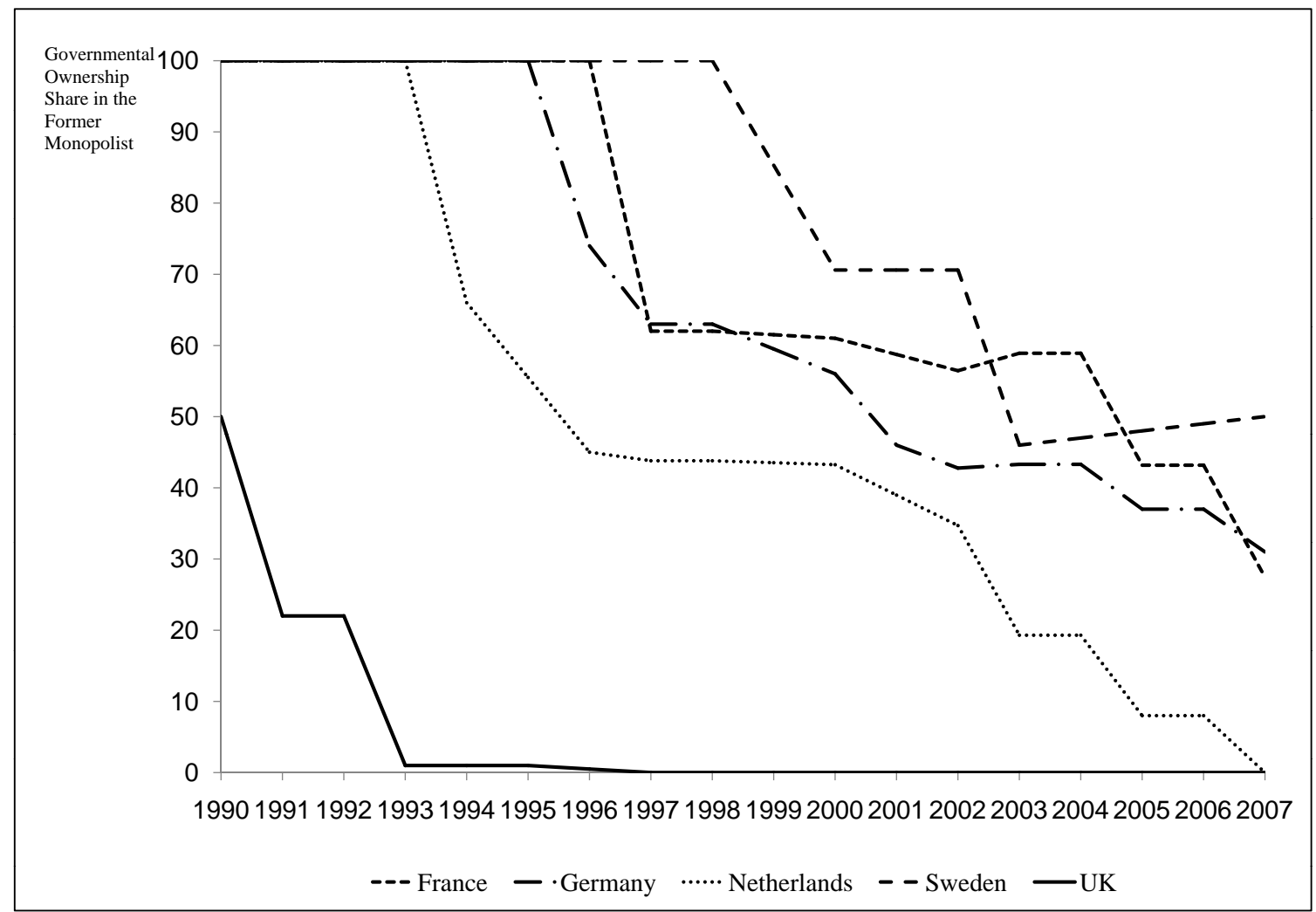

Source: Data taken from the OECD Regulatory Index

Following the literature, multiple reasons exists for governments' involvement in companies. One key aspect for public participation is exercising control rights. Minoritystake participation enables governments to affect strategic changes within the incumbent, which comprise its separation or its acquisition by a competitor (Bel and Trillas, 2005). As the EC has multiply brought cases to the European Court of Justice about GoldenShares rulings in member states,${ }^{13}$ minority participation is a legal equivalent to secure public interests.

\footnotetext{
$\overline{{ }^{13} \text { Examples are Portugal (2002) or Spain }}$ (2003).
} 
The EC heavily criticizes public involvements in former telecommunication monopolists as it suspects such an ownership constellation to affect regulation and competition in the telecommunication sector as a whole. The regulatory framework requires a strict separation of the regulatory agency-related authorities and the authorities administrating shares in the incumbent provider to alleviate the challenge of governmental influence on the sector development. However, in multiple cases, such as France before 2001 or the Czech Republic even in 2008, the EC still expresses concerns about an adequate implementation of separation.

Governments typically use control rights to follow sector-related or macroeconomic aims such as infrastructure provision of adequate quality and infrastructure roll-out to stimulate growth aims also in other sectors. The governmental intention of infrastructure provision deviates from managers' intention as telecommunication providers cannot completely internalize the economic benefits derived from infrastructure provision. Based on control rights, governments are able to influence the decision process for long-term investments directly balancing infrastructure roll-out concerning regional reach and concerning innovative technological infrastructure provision. Governments are aware of the capability of telecommunication infrastructure as an instrument for attracting high-potential companies in international competition with other countries, also within the EU. Thus, in contrast to the management of infrastructure providers, governments balance sectorspecific competition aims, i.e. static regulation aims, with macroeconomic aims, which mainly refers to investments to provide a high-quality infrastructure for users.

While the EC cannot restrict a national government's macroeconomic strategy (even if this strategy causes rivalry among EU member states) it intervenes on the sector-level if such a strategy benefits one company over competitors. Such a case recently occurred in Germany, where the national government wanted to provide regulatory holidays to the incumbent, so that it could roll out its very high-speed internet network (VDSL) to selected cities. Consensus exists among providers, Deutsche Telekom and also its competitors, and the government that VDSL will have a positive impact on economic growth as a whole. However, the EC expected a first-mover advantage after the installation of VDSL for the incumbent on the service level due to regulatory holidays. Therefore, it abolished the decision of the German government and brought a case to the European Court of Justice. The court followed the argumentation of the EC and, in December 2009, prohibited the necessary adjustments of the German telecommunication law. 
While governments are less interested in maximizing shareholder values, their key interest lies in exercising control rights to follow sector aims and macroeconomic aims. In contrast to managers, governments seek total welfare maximization, which differs from profit maximization due to comprehensive positive externalities of telecommunications on other industries.

\subsection{State Aid and Active Public Participation}

Comparing the situations before and after the liberalization shows that the role of telecommunications has dramatically changed from a sector which provides subordinated support for other sectors to one of the key sectors, if not the key sector, for economic growth in all developing and developed countries. ${ }^{14}$ While physical infrastructure investments are a requirement not only for the development of the telecommunication sector but for the economy as a whole, infrastructure operators can hardly internalize the positive externalities which they provide to other sectors and households. ${ }^{15}$

State Aid is an instrument to control infrastructure investments from a macroeconomic perspective compensating at least partially for externalities provided by a high-quality infrastructure. It enables governments to install rules which separate infrastructure installation from downstream competition, thus, reducing the potential first-mover challenge repeatedly mentioned in line with vertically integrated providers of an essential facility.

Concerning the alternative instruments, I follow the EC definition of state aid:

"State aid is defined as an advantage in any form whatsoever conferred on a selective basis to undertakings by national public authorities." 16

Based on this very broad definition, direct financial support, i.e. either monetary support or asset support, and privileges, like tax reductions, or legal burden reductions, like regulatory holidays, have to be distinguished. ${ }^{17}$

Both the EU and national authorities provide public aid in telecommunication markets either to expand infrastructure quality in less lucrative regions or to increase infrastructure quality in economic key regions. Moreover, also regional and municipal authorities

\footnotetext{
${ }^{14}$ Röller and Waverman (2001) and also subsequent studies by Waverman find telecommunications and, in particular, broadband to be a key driver of economic growth.

${ }^{15}$ The impact of service competition and the impact of derived demand for infrastructure is considered in Veith (2010a).

${ }^{16} \mathrm{http}$ ://ec.europa.eu/competition/state_aid/overview/index_en.html

${ }^{17}$ An overview of state aid decisions since 2000 is provided in Table 2 in Appendix .
} 
support infrastructure investments. While European and national aid are mainly monetary grants for infrastructure roll-out, on the lower administrative level, various additional forms of public support are in place, which even include public private partnerships (PPP) with public authorities involved in administrative and control decision processes of the network provider (comprehensively in Sweden and France).

Two types of public aid have to be considered separately, which are financial and nonfinancial support.

Figure 2: Financial versus Non-Financial State Aid

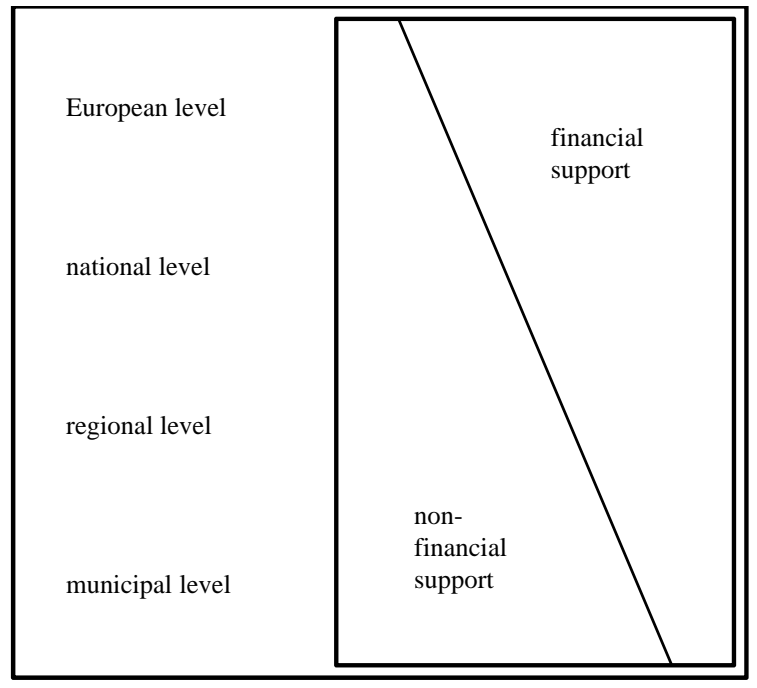

\section{Financial Support}

European authorities provide mainly financial support for network operators. In doing so, they assist the infrastructure roll-out in less densely populated areas and in less developed countries. Financial support comprises a pre-determined, mostly fixed amount for a particular project or part of a project. As a common level of infrastructure quality facilitates the integration of multiple national markets and the provision of similar services across all member states, the EU has a strong interest to reduce quality differences in single countries and across countries. A high infrastructure-quality level across all member states provides a major advantage for attracting companies with an international focus as a high quality telecommunication infrastructure complements the existing high quality transportation infrastructure. The combination of both high-quality transportation infrastructure and high-quality telecommunication infrastructure are key assets for European countries in worldwide competition. 
National governments offer both financial support and non-financial support for infrastructure roll-out. Financial grants are used to increase national infrastructure quality as a whole or to reduce the urban-rural differential of infrastructure quality. In consequence, financial grants foster the installation of new transmission technologies like broadband as e.g. in Sweden. Sweden financed the installation of broadband infrastructure to the centers of Swedish cities. While this strongly increased the acceptance of broadband internet by the Swedish population at an early point in time, it also provided a major advantage for the incumbent over new competitors, as it was the only Swedish provider, which could afford the installation task at that time. In combination with the restrictive regulatory policy and, thus, the low level of access competition, the competitive advantage for the incumbent was even stronger. In France, an alternative state aid strategy is in place in line with broadband initiations. Private broadband installation started at Paris and the surroundings of Paris and major cities such as Montpellier or Lyon, while rural areas were not that attractive for the incumbent and other providers. Therefore, municipal administrations supported by the national government addressed the issue funding broadband roll-out based on PPPs. As national and municipal administrations subsequently demanded decision rights and an adequate return on investments in line with local loop access, the EC heavily criticizes national and municipal governments' claims (Implementation Report 2000).

Figure 3: Infrastructure Projects Accompanied by Financial Aid

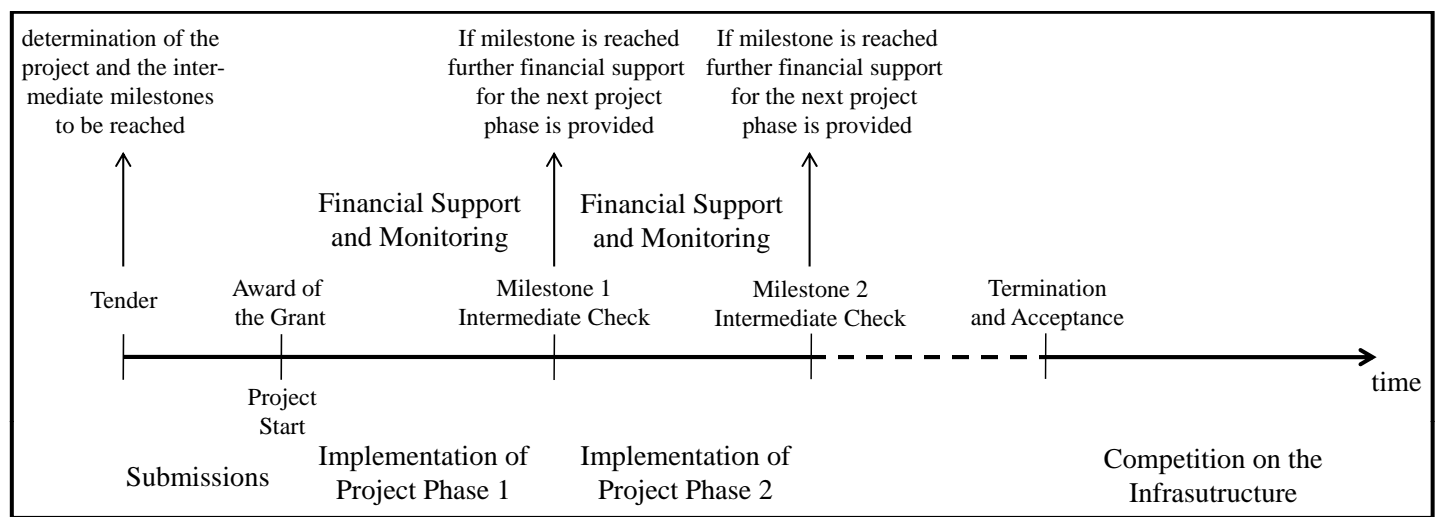




\section{Non-Financial Support}

On the national and the sub-national levels, financial support is accompanied by additional privileges. In contrast to financial support, non-financial approaches are under much more discussion. Although the Access Directive requires non-discriminatory end-to-end user access (Access Directive (2002/19/EC), Article 3(1)), the provision of particular privileges enables infrastructure operators to discriminate between alternative providers depending on the access price. Similar to financial support, privileges enable the beneficiary to refund its investments. However, non-financial support requires a more comprehensive set of rules, which guarantee the installation of an adequate path to competition after the period of privileges while, simultaneously, investors must refinance their investments.

As already discussed in the previous subsection, VDSL roll-out in Germany is an example for granting specific legal rights to an infrastructure provider. The German national and the Länder-governments have amended the German telecommunication law in the sense that new high-speed transmission technology is excluded from regulation. ${ }^{18}$ As described above, the EC suspected a first-mover advantage for the incumbent as it would be able to decide on competitors offering services on the new infrastructure (contradicting Article 8 and other articles of the Framework Directive). However, the first-mover advantage remains a point of discussion as the EC definition does not exclude privileges for single investors from state aid.

Moreover, specific legal rules could be used as an instrument to provide investment incentives for single infrastructure providers or a small group of infrastructure providers. But, in difference to most examples known from the past, such rules require a high level of transparency and project knowledge both from monitoring and controlling institutions and from the granted companies. ${ }^{19}$ In addition, depending on the complexity of the project, pre-determined rules have to provide strict milestones, which are controlled and, if necessary, enforced by the controlling institutions which should be the regulator. However, transparent rules need not guarantee the success of the project but offer an economically realistic perspective for investments and their refunding.

This aspect is of particular importance with regard to the critical mass effect in social network-based markets. The critical mass describes the number of customers who are necessary for the sustainable existence of a social network. It is assumed that customers

\footnotetext{
${ }^{18}$ Actually, the proposition did not grant the privilege to the incumbent. However, no alternative infrastructure provider was able to benefit from this specific ruling.

${ }^{19}$ While these requirements should also accompany projects supported by a financial public grant, they are only implemented in a small number of projects.
} 
attract new customers, e.g. based on "friendship"-programs being locked-in with a particular company due to network size and "friends" being with the same provider. Thus, granting non-financial state aid must take into account the first-mover advantage of a vertically integrated investor as it is a highly relevant aspect of refinancing the project. In consequence, the phase of independent access control by the investor must be kept flexible and has to be controlled very carefully by the regulator. Pre-determined and commonly accepted rules have to be established at the beginning of the project. In particular, the phase of independent access control does not need to cover the total refinancing due to the first-mover advantage of the investor and the installed customer group before competition is allowed.

Figure 4: Infrastructure Projects Accompanied by Non-Financial Aid

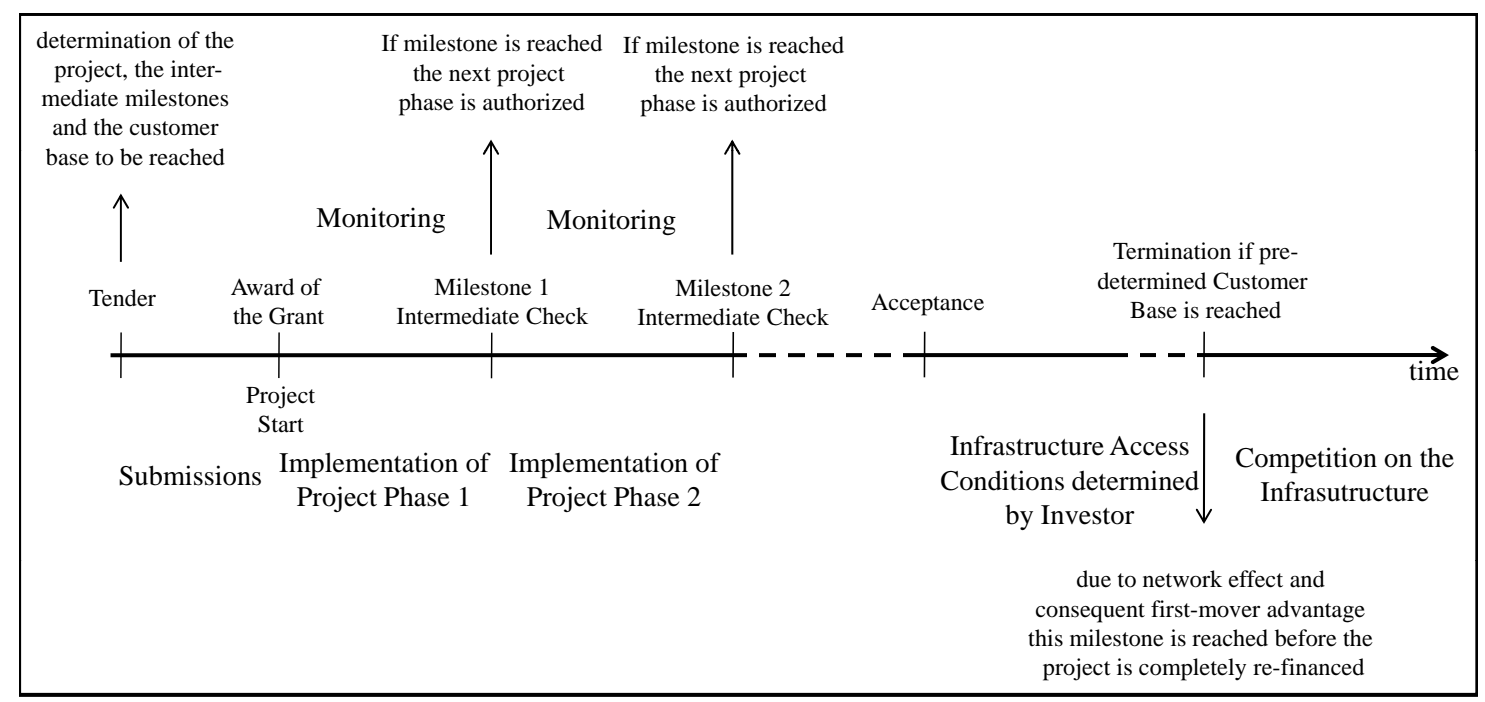

\section{Comparison of Financial and Non-Financial Support}

Comparing projects with financial and with non-financial support (Figures 3 and 4) shows that non-financial aid demands a longer period of project support as the refinancing phase begins after the investment phase(s). In consequence, non-financial support also requires a more complex preparation, as the critical mass aspect has to be taken into consideration already in the project preparation phase. Non-financial state aid shifts the balanced consideration of chances and project risks in the direction of the investor as the responsibility for re-financing is with the investor. However, the investor is also informed in much more detail about the status of investments than the provider of a grant and also about the status of the project as a whole. Due to 
the ex-ante unclear development of the customer size, non-financial support demands also much more flexibility in the post-investment phase. These additional assumptions require a highly structured preparation of non-financial projects. However, adequate preparation and training of NRA employees should already be installed for monitoring public financial aid projects.

\subsection{Combining Roles to Affect the Integration Process}

While I have considered the dichotomous roles of the government separately so far, the common effect of combining multiple strategies should not be ignored, as this could have a much stronger impact on the sector and on market developments and could be used to foster the European integration process even more than simply regulation can achieve. An example of such a strategy is the combination of legal rule settings and public grants to foster investments. Adequate and transparent rules are the pre-condition for a sufficient tender. If lawmakers offer an adequate framework under which conditions such tenders could be constructed and also enforced, this would facilitate the installation of a grant and would strongly increase transparency during the implementation phases. Another example in this direction is the provision of an adequate legal system and its enforcement by the national regulator. A stronger proximity of regulators to markets requires also an efficient internal structure, which enables a less bureaucratic and prompt reaction to market changes. The information gained from such a proximity to markets could also run into the long-term oriented provision of a sufficient legal system as is shown in the UK.

On the other hand, governments could also follow the opposite strategy. Insufficient lawmaking and, simultaneously, strategically delaying NRAs' decision powers hamper the integration process.

However, while the EC intends to reduce the influence of national governments on the telecommunication sector, positive examples provide evidence that it could use the longterm interrelationship in the integration process to strengthen the European position as a whole. E.g. coordinating national governments' activities and their roles in the national telecommunication sector could be used to foster the interconnection of national infrastructures forming a pan-European telecommunication infrastructure to broaden the basis for pan-European market integrations. 
The telecommunication sector is in the focus of a magnitude of governmental interventions. I have highlighted mainly four key types of interrelationships between public authorities and the sector with a particular focus on the challenges of investments and the installation of competition, which are providing the legal framework for the sector performance, affecting strategic decisions within the sector regulator, ownership participation of the former monopolist and public aid in the context of infrastructure projects. The consideration focuses on problems learned from past cases and provides some introductory discussions based on the literature and EC recommendations. With regard to the legal system and the regulatory structure, entrant companies and the EC repeatedly mentioned the lack of contemporary and transparent regulatory rules and their implementation. With regard to companies and projects, the major challenge remains the internalization of positive externalities from infrastructure provision on other industries and customers.

\section{Extension: The Third Regulatory Package}

In December 2009, the European Parliament introduced the Third Regulatory Package, which has to be implemented to national laws until mid 2011. This new regulatory framework takes up various criticisms brought forward in line with its predecessors and fosters the national implementation process by providing stricter rules. In this extension, I consider the key changes in the light of the current market situations. ${ }^{20}$

\subsection{Infrastructure Investments and Competition}

As described above, the current regulatory framework balances the two aims of initiating investments and enforcing competition and leaves the priority decision to national governments and NRAs. National governments implement investment aims with varying efforts, which results in different levels of national infrastructure qualities and infrastructure competition in particular in the local loop. ${ }^{21}$ The new regulatory framework attaches more attention to dynamic regulation aims, as the reviews under the current Regulatory Package provided evidence for upcoming competition. Based on the aims of the Lisbon Agenda, the new Regulatory Package further supports innovation aims on the

\footnotetext{
${ }^{20} \mathrm{~A}$ more detailed consideration of the changes in line with the Third Regulatory Package is provided in Appendix . In this extension, I only consider the key changes concerning the discussions of the previous sections.

${ }^{21}$ Please see Figure 6 in Appendix .
} 
service level by promoting the roll-out of high-quality infrastructure. In consequence, the new regulatory framework demands the installation of regional lead-market projects to foster the international competitiveness of the EU.

Turning from balanced competition and investment aims to a stronger focus on highquality-infrastructure investments, Article 8 of the 2002 Framework Directive on policy objectives and regulatory principles has been comprehensively revised in two directions: The proposal for Directive 2009/140/EC ${ }^{22}$, the amendment of Directive 2002/21/EC, requires national governments and NRAs to appropriately take into account the risk incurred by investors and proposes new forms of co-financing investments which have already been implemented in single member states (adjustment 8h (5d)): In particular, cooperative arrangements between infrastructure providers and service providers foster the internalization of externalities of a high quality infrastructure.

While this adjustment is established to facilitate the integration of positive infrastructure externalities, it can only partially alleviate the existing challenge: Service providers demand high upload rates and are therefore settled in regions with high infrastructure quality, which means urban areas. Thus, service providers are not necessarily interested in supporting the infrastructure roll-out in less-densely populated areas. As returns on infrastructure installation in urban areas are higher and less risky, the integration of service providers into the investment process alleviates the challenge of high quality infrastructure provision in urban areas. However, such an approach increases the urbanrural infrastructure quality differential without cross-regional subsidization.

Besides regional lead-market approaches for fix-line infrastructure quality, the new regulatory framework enhances facility-based local-loop competition by opening more (also denser) radio frequency bands for public usage. Following the communication of 20 March 2006, titled "Bridging the Broadband Gap", the EC explicitly mentions frequency bands to be an adequate and cheeper instrument for providing higher-quality broadband access to less profitable regions. Although having lower transmission capacities than fix-line broadband transmission systems, radio-frequency-based approaches increase the existing level of broadband infrastructure in rural areas at lower costs compared to fix-line infrastructure installation.

\footnotetext{
${ }^{22}$ http://ec.europa.eu/information_society/policy/ecomm/doc/tomorrow/reform/better_ regulation_directive/st03677_re06.en09.pdf
} 
Besides the increase in investment flexibility, the German Monopolies Commission highlights mainly five changes in line with the Third Regulatory Package in its latest Special Opinion on telecommunication markets (Monopolies Commission, 2009), Co-Regulation, Independence of NRAs, Functional Separation, the European Regulatory Body and the Harmonized Implementation of Guidelines. I will shortly discuss them in the light of the previous sections.

\subsection{Co-Regulation}

For a better harmonization of regulation in the EU member states the European Parliament introduced a new regulatory stage for national governments and NRAs. Drafts for new market definitions, market analyses and the introduction of new regulatory measures have to be announced to the EC, other NRAs and the BEREC (Body of European Regulators of Electronic Communication). ${ }^{23}$ Each of these institutions can provide further suggestions and comments, which have to be taken into account when implementing new measures. The EC and the BEREC can veto draft versions of market definitions and market analyses in coordination with the other if they suspect the proposals not to correspond with European guidelines.

In contrast to the previous regulatory approaches, this new instrument seeks a better coordination of national regulations. However, it increases complexity as it requires NRAs to inform other parties not familiar with the national situation about new regulatory steps and, additionally, it demands NRAs to analyze the regulatory approaches brought forward in other member states. Thus, co-regulation comprehensively increases the workload of NRAs and extends the implementation of regulation to the market. Following the Special Opinion of the Monopolies Commission, this new approach complicates the already complex regulatory system. ${ }^{24}$ While co-regulation should foster the European integration process, it extends the national implementation of regulation, which will expectedly reduces regulatory efficiency as a whole as examples in line with the introduction of local loop unbundling have proven in many EU member states.

\footnotetext{
${ }^{23}$ More information on the BEREC is provided below and in Appendix .

${ }^{24}$ More information on this issue is provided in Veith (2010b).
} 


\subsection{Independence of NRAs}

Following the new Framework Directive, national regulatory bodies and the presidential chambers shall become more independent from the national political system. In particular, when implementing European guidelines to national markets, the NRA shall not be allowed to demand for consultative political support and it will also not be allowed to accept such support. Moreover, presidents of NRAs and their vice-presidents must not be dismissed without violating national requirements for their tasks.

These more stringent rules support the recommendations in line with the discussion on NRAs' dependence on national political systems under the Second Regulatory Package. While the current guidelines try to guarantee the independence of decisions by separating the ministries in charge for administrating shares in the regulated incumbent and the NRA, these new rulings additionally require the independence of the NRA as far as possible from any political powers. This new independence reduces the broadly suspected and also observable interference on NRAs. However, it remains to be seen how this stronger sovereignty of NRAs affects regulation and the outcome of national markets in terms of more competition and efficiency.

\subsection{Functional Separation}

Functional separation implies the separation of the network-operating unit and the service unit of a vertically integrated company. Functional separation shall provide nondiscriminatory access conditions for service providers compared to the vertically integrated operator, as this provider has a strong incentive to affect service competition based on the access price or the access conditions to its essential input. This type of separation has been introduced in the UK and in Denmark and has been considered as a regulatory option also in other countries already under the Second Regulatory Package. Multiple arguments brought forward in the literature question this approach at the current stage of regulation and market competition. Firstly, functional separation is not sufficiently defined in the Regulatory Package. Examples known from the economic literature hint at the challenges of monitoring a functionally separated company (Vickers (1995) for reasons of information asymmetry, Sappington (2006) for reasons of non-price discrimination, and subsequent studies on these topics). Secondly, the analyses of other NRAs after the UK approach and also the considerations in the economic literature (Cave, 2006b; Whalley and Curwen, 2008) show that the complexity of separation 
and monitoring the separated company might comprehensively increase the workload of NRAs with their current organizational structures. Thirdly, the German Monopolies Commission argues that functional separation is an extensive instrument, which should have been implemented at an earlier stage of the transition process. But it will not foster competition in the current, more developed situation of markets in the integration process.

Following these alternative points of criticisms, it is not clear whether national regulators will actually implement functional separation, in particular in EU-15 member states, which questions the necessity of this instrument as a whole.

\subsection{The pan-European Regulatory Body}

The BEREC (Body of European Regulators for Electronic Communications) will be a common European regulatory body consisting of the heads of the national regulators, which will support the EC in the adoption of new regulatory measures. In contrast to its predecessor, the ERG, this new institution will not only consult the EC on national issues but it will also have the opportunity to veto national regulatory measures if it suspects them to be insufficient or not in line with European regulatory guidelines.

While its decision powers are more comprehensive than the decision rights of the ERG, the BEREC is a trade-off solution, which leaves key competencies with national regulators and, thus, leaves major sovereignty at the national level. On the one hand, decentralized regulators have a stronger proximity to national and sub-national markets and, therefore, will probably react prompter to market issues in the future. On the other hand, the current form of the BEREC's decision rights with its veto powers complicates the implementation of national regulatory decisions as not only the EC but also the BEREC is allowed to intervene based on the co-regulation approach.

\subsection{Harmonized Implementation of Guidelines}

Previous regulatory measures by the EC had to be transposed to national laws taking into account national distinctions. With the new Regulatory Package, the EC is able to order how common regulatory rules have to be implemented to national markets. This stricter ruling reduces national governments' influence in the transposition process and, in particular, also with the implementation of specific regulatory interventions.

One can show that directed European interventions reduce uncertainty in addressed mar- 
kets in comparison to indirected interventions (Veith, 2010b). However, the adoption of a particular regulatory rule to a group of all member states' markets ignores different stages of competition or infrastructure quality. While this approach is a reasonable attempt for harmonizing international telecommunication markets between member states, ignoring national distinctions might, currently, enhance the acceptance in national markets. Therefore, it does not necessarily foster the integration process as national markets still exhibit major technological and economic differences.

The Third Regulatory Package is to a far extent based on its predecessor regulatory framework. It takes up key aspects of criticisms and provides stricter rules which support the ongoing integration process. Concerning infrastructure provision and competition, the new framework emphasizes the importance of the infrastructure as an enabler of higher-quality services and as a key requirement for other industries. For internalizing comprehensive externalities with infrastructure provision, the new Regulatory Package allows infrastructure providers to take into account the cost of capital as a cost component, which facilitates the internalization of externalities provided by infrastructure investments in access price negotiations. Moreover, the new regulatory framework increases regulatory independence from national governments.

However, it also provides some measures, which require further attention as the effectiveness of these measures is unclear with the current stage of competition in the EU member states (e.g. functional separation) and as they ignore differences between the current stage of competition across EU member states.

\section{Conclusion}

I considered the alternative roles of the government in the context of providing a highquality telecommunication infrastructure and installing competition in infrastructure and service markets. The telecommunication sector is considered to be a key sector for other industries and, therefore, is also a key driver of economic growth. National governments are aware of this relevance of telecommunications and, consequently, seek to influence its development to meet national requirements most effectively. While governmental interventions in the sector facilitate the internalization of externalities by infrastructure providers, governments follow aims on the national level, which do not necessarily correspond to the aims on the European level. 
Governments keep strong interrelationships with the telecommunication sector as they provide telecommunication laws and determine the national transposition of European guidelines. However, the transposition process has been repeatedly in the focus of criticisms as competitors and also the EC charge the transposition process to be inefficient and, thus, to benefit providers with larger market shares, mainly former monopolists. Strong interrelations also exist between national regulators and the government, as national regulators are successor organizations of ministries or administrations when only one telecommunication provider was active in a market with a low level of technological deployment. As organizational structures of regulatory bodies strongly affect market proximity, telecommunication companies criticize the competence of regulators' employees and the decision process as being too slow and ignoring the actual challenges of the markets. By adjusting organizational structures, some regulators reacted to these aspects of criticism and, in doing so, found solutions for securing their knowledge stocks independently from individual employees. The comparisons of these re-organized regulators and "traditional" institutions provides evidence for much more efficiency with the more flexible structure. Therefore, these countries are much less under suspicion of the $\mathrm{EC}$ as is proven by the Implementation Reports.

Besides the jurisdictional relation of governments with the telecommunication sector, governments are also active on the company- and the project level: Most EU member states keep minority stakes of their former monopolists even today, which secures them from unfriendly takeovers. However, governments follow mainly other aims with their participations in telecommunication companies. As telecommunication infrastructure is a key pre-requisite for innovations and investments on the service level and also in other sectors, governments are interested in the provision of a high-quality telecommunication infrastructure. However, infrastructure providers can hardly internalize the increasing externalities provided by their investments. National governments as well as European administrations and sub-national governments reduce the challenge of internalizing investment externalities by providing public support for infrastructure rollout. While financial aid is the common type of support, non-financial support needs particular attention as it leaves the analysis of investment chances and risks with the (better-informed) investor. Although non-financial support is an accepted type of state aid, the EC criticizes it of being in-transparent, which reduces the field of re-financing investments and, therefore, is an issue to be considered in more detail in future work. 
Comparing the alternative roles of the governments provides evidence for a strong interrelationship of public administrations and governments with national telecommunication markets. Combining the instruments of the alternative roles even increases the power of national governments. While European administrations continuously try to reduce the impact of national governments within the sector and foster market integration mainly with regulatory requirements, the discussion provided here raises the question whether the European integration process could benefit from the strong impact of national governments on the national telecommunication sector.

The latest Regulatory Package takes up key points of criticism and offers new approaches to meet obstacles with its predecessors. However, while competition is to a far extent installed on the service level, efficiency is a key issue to be addressed not only in regulated markets. Moreover, it also has to be addressed in the national regulatory structures in combination with transparency to foster the provision of investment incentives both to increase innovations and to provide a high-quality infrastructure within and across all EU member states. 


\section{References}

Bauer, J., And E. Bohlin (2007): "From Static to Dynamic Regulation Recent Developments in U.S. Telecommunications Policy," Working Paper, pp. 1-29.

Bel, G., And F. Trillas (2005): "Privatization, Corporate Control and Regulatory Reform: The case of Telefonica," Working Paper, pp. 1-25.

Broos, L. C., M. A. Heldeweg, and R. A. Wessel (2009): "European Organization of Telecom Regulators and the Impact on the Pace of Telecom Innovations: Is EU Modesty Hampering Innovation in Telecom? Think Global, Act Local...," Working Paper, pp. 1-18.

Cave, M. (2006a): "Encouraging Infrastructure Competition via the Ladder of Investment," Telecommunications Policy, 30(3-4), 223-237.

(2006b): "Six Degrees of Separation: Operational Separation as a Remedy in European Telecommunications Regulation," Communications \& Strategies, (64), 89-103.

(2009): Regulating Telecommunications in Europe: Present and Future in Internet Policy and Economics. Springer US, 1 edn.

DE BiJl, P. W., And M. Peitz (2005): "Local Loop Unbundling in Europe: Experience, Prospects and Policy Challenges," Communications \& Strategies, (57), 33-57.

Duso, T., And L.-H. Roeller (2003): "Endogenous Deregulation: Evidence from OECD Countries," Economic Letters, 81, 67-71.

European Regulators Group (2007): "ERG Opinion on Functional Separation," Working Paper, pp. 1-14.

GrajeK, M., And L.-H. RÖller (2009): "Analysing the Relationship between Regulation and Investment in the Telecommunication Sector," esmt Working Paper, pp. $1-57$.

Heald, D. A. (1997): "Public Policy Towards Cross Subsidy," Annals of Public and Cooperative Economics, 68(4), 591-623.

Knieps, G. (2007): Netzökonomie - Grundlagen, Strategien, Wettbewerbspolitik. Gabler Verlag, GWV Fachverlage, 1 edn.

Levy, B., AND P. T. SpILler (1994): "The Institutional Foundations of Regulatory Commitment: A Comparative Analysis of Telecommunications Regulation," Journal of Law, Economics and Organization, 10(2), 201-246.

(1996): Regulations, Institutions, and Commitment: Comparative Studies of Telecommunications. Cambridge University Press, New York, 13 edn. 
Nikogosian, V., and T. Veith (2010): "Non-Price Discrimination in Retail Electricity Markets," Working Paper, pp. 1-23.

Peltzman, S. (1976): "Toward a More General Theory of Regulation," Journal of Law and Economics, 19(2), 211-240.

Persson, T., and G. E. Tabellini (2000): Political Economics. Explaining Economic Policy. The MIT Press, Cambridge, Massachussetts, 1 edn.

Sappington, D. E. (2006): "Regulation in Vertically-Related Industries: Myths, Facts, and Policy," Review of Industrial Organization, 28(1), 3-16.

Stigler, G. J. (1971): "The Theory of Economic Regulation," Bell Journal of Economics, 1(2), 3-21.

Veith, T. (2010a): "Supply and Demand for Telecommunication Infrastructure," $Z E W$ Discussion Paper, pp. 1-35.

(2010b): "European Telecommunication Regulation — Effects on Telecommunication Providers," ZEW Discussion Paper, pp. 1-37.

Vickers, J. (1995): "Competition and Regulation in Vertically Related Markets," Review of Economic Studies, 62(1), 1-17.

Waverman, L., AND L.-H. RÖLler (2001): "Telecommunications Infrastructure and Economic Development: A Simultaneous Approach," American Economic Review, 91(4), 909-923.

WeizsäCKeR, C. C. V. (2008): "Regionalisierung der Regulierung im BitstromzugangsMarkt," Gutachten, pp. 1-30.

Whalley, J., And P. Curwen (2008): "Is Functional Separation BT-Style the Answer?," Communications \& Strategies, (71), 145-165. 


\section{Appendix}

\section{Market Access and Privatization}

Figure 5: Steps to Competition on EU-15 Telecommunication Markets

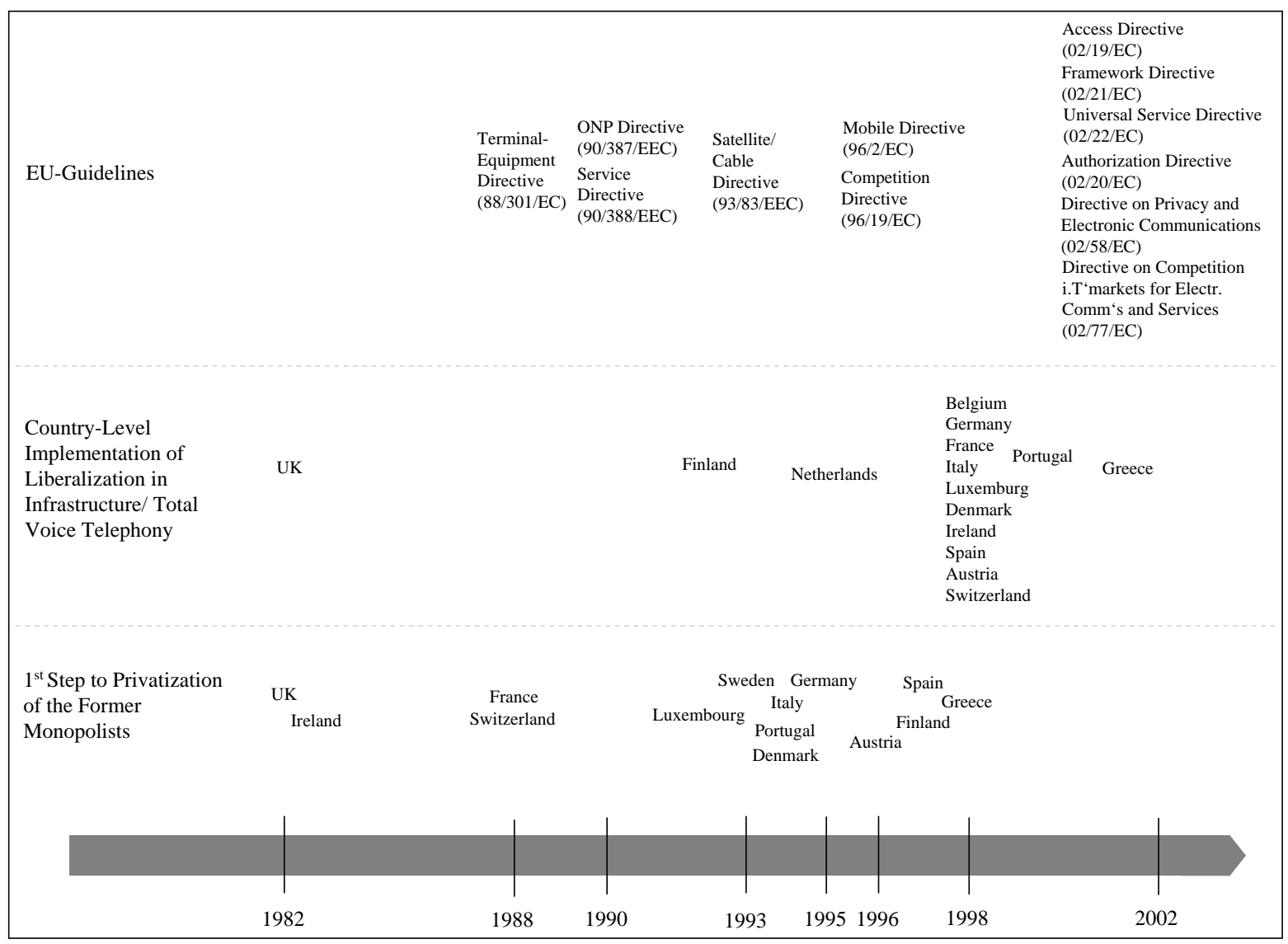

The figure above shows the introduction of the EU Telecommunication Directives. The most important directive was the 1996 Competition Directive which opened both infrastructure and voice transmission markets for competition.

The second line shows the entrance of the first competitor on fix-line telecommunication markets. In most countries, new firms were allowed to enter the markets by the implementation of the EU Competition Directive in national law in 1998.

The last line shows the year when governmental ownership over the former monopolists have been reduced for the first time. As could easily be seen, liberalization always occurred after privatization in the countries under scrutiny. 


\section{Infrastructure Competition and Investments - a Comparison of Performance}

Two main reasons exist why one observes European telecommunication markets in alternative stages of competition in different countries: 1) National member states have been at a different competition status when the liberalization of European telecommunications markets was implemented and 2) member states are obliged to adopt the EC directives taking into account national distinctions. Due to these different starting points, the EC has a strong interest in aligning the status of national markets for preparing the integration to one European market. As national governments do not only pursue the European integration policy but follow own national or also individual interests, their actions affect the transposition process and also the national stage of competition.

Figure 6 displays the relation of DSL- and cable-based broadband access over time (Figure $7(\mathrm{a})$ ) and unbundled access lines in relation to the total access lines available for fix-line telecommunication networks (Figure $7(\mathrm{~b})$ ) over time. The first graph shows a strong bulge for Germany and also for France, whereas the relation in smaller countries is much more balanced, in particular for the Netherlands. Following Cave (2009), a reason for the difference between facility-based competition in larger and smaller countries comes from the availability of cable access. For example, in Germany, cable has been available only in cities and there is still no tendency of cable providers to roll-out networks. Moreover, the German telecommunication incumbent held stakes in regional cable companies until 2003, which might have delayed cable as a medium for internet access as argued by the EC in multiple Implementation Reports. In France, a similar situation is observable, where cable networks are also concentrated in major agglomerations. Following the 2002 Implementation Report, after 2001, investments slowed down in France as the Conseil de la Concurrence, the French competition authority, forced the incumbent to give access to its local loop infrastructure. However, municipal administrations in less densely populated areas arranged with the telecommunication incumbent to join investments based on bilateral agreements. Such new forms of financing DSL roll-out led to an ongoing increase of the gap between DSL and cable usage for broadband access.

Due to the overall availability of low-speed telecommunication networks, a first-mover advantage of DSL infrastructure over cable infrastructure exists, as investment costs are lower for installing adequate transmission technology than for rolling out a new infrastructure. Exceptions are the Netherlands and also the UK where cable is nearly as widely spread as telecommunication infrastructure.

While the last-mile physical infrastructure is commonly agreed to be a monopolistic bottleneck (see e.g. Bauer, 2007, or Knieps, 2007), the access to frequency bands on this infrastructure is particularly relevant for the take-up of local loop competition. Cave's ladder-of-investment model (Cave, 2006a) shows that new competitors enter a market, firstly, getting access to an incumbent's infrastructure by renting or leasing access capacity and, subsequently, building out own infrastructure. Thus, following Cave (2009), 
it is important to focus wholesale regulation on a few access elements, and to increase the attractiveness for potential competitors to enter the local market. If they are able to gain sufficient market shares subsequent physical infrastructure investments by new entrants will follow. In a next step, it is therefore necessary to consider how local loop unbundling has been introduced and guaranteed in EU member states.

In its Regulation No. 2887/2000, the EC provides a detailed description about how local loop unbundling should be implemented on the national level, gives detailed information about the elements included at the minimum and provides the date by which infrastructure owners are obliged to provide an offer to competitors, which is 31 December $2000 .^{25}$ Figure 7(b) shows the local loop unbundling development expressed as the share of unbundled local loops per fix-line access paths. Although local loop unbundling should be implemented to local loops at the earliest point in time when it is feasible, since 2000, local loop unbundling is available only to about one fifth to one fourth of all lines in 2007. As local loop unbundling is the key requirement for providing competitive services to customers, the EC suspects many former monopolists trying to delay the access for new entrants.

\section{Local Loop Competition - Comparison across EU Member States}

Comparing the individual country developments with regard to market opening, the UK is found to be the first country with actual local loop unbundling rules in place already in 1997. However, OFTEL, the UK NRA, decided not to require access to raw copper lines as it suspected competitors delaying the roll-out of own infrastructure otherwise. In line with competition stimulation, the UK NRA required new entrants first to negotiate access prices to collocation points. Only if negotiations failed the NRA would intervene. With regard to services on the lines, the NRA tied the vertically integrated incumbent to allow ADSL provision only if, simultaneously, an adequate wholesale product is available. While the UK market was lagging far behind other countries in terms of competition, after around 2005 a strong catching-up of the local loop unbundling market took place, as the incumbent functionally separated its service units from the infrastructure units. Due to the separation, OFCOM, the successor of OFTEL, decided to relax wholesale line rental regulation as it expected the market to be in a state of competition.

Local loop unbundling has been implemented stepwise in Germany since 1998 based on fully unbundled raw copper, whereas shared access and also sub-loop unbundling (a particular necessity with the fiber-based Opal technology in Eastern Germany) was denied. Concerning interconnection, the EC suspected the German incumbent systematically to delay the availability of a sufficient number of collocation points. Deutsche Telekom offered ADSL services since mid-1999 and competitors were allowed to resale ADSL products from the same point in time.

In France, the incumbent has offered retail ADSL services since November 1999. How-

\footnotetext{
${ }^{25}$ http://eur-lex.europa.eu/LexUriServ/LexUriServ.do?uri=0J :L : 2000:336:0004:0008: EN : $\mathrm{PDF}$
} 
ever, wholesale offers were not available until an intervention by the French competition authority in 2001, when the incumbent was obliged to unbundle its local loop for full and shared access. Competitors complained about the comprehensive first-mover advantage of the incumbent, in particular, as ADSL was blocked by the incumbent even after the decision. Nevertheless, the courageous intervention by the competition authority resulted in a strong increase in unbundled access lines which is even stronger than in other countries and led to the second highest rate of unbundled lines in the EU-15 (behind Finland). ${ }^{26}$

While local loop unbundling was implemented in the Netherlands in June 2000, about 90 percent of the unbundled lines were provided to a subsidiary of the incumbent. Moreover, until 2001, competitors claimed that the way of providing collocation points circumvented last mile competition as, firstly, too few collocation facilities were offered in major agglomerations and, secondly, the incumbent gave no information about the availability and characteristics of collocation facilities in advance. In consequence, the incumbent and its subsidiary gained a comprehensive first-mover advantage over their ADSL competitors. However, entrants can also use cable providers' infrastructure to get access to customers, but this infrastructure is not covered by the telecommunications regulatory framework.

The Swedish incumbent opened its local loop voluntarily by offering local loop access and collocation facilities without national regulatory interventions in March 2000. Thus, competitors were able to negotiate full local loop access or shared access based on bilateral contracts with Telia. However, Telia refrained from providing sub-loop access. Since September 2001, Telia offers a wholesale ADSL product bundle for resale. Following the EC, still too few competition existed in 2001 as the prices claimed by the incumbent were too high both for local loop access and also for the wholesale ADSL offer. As a high market concentration still existed in 2004, PTS, the Swedish NRA, intervened ordering Telia to provide access to the local loop under non-discriminatory conditions to all demanding companies.

${ }^{26}$ Ranking of the five countries considered here in 2007 (2003 (due to missing information for many countries in 2002)): France: 2 (6), Germany: 3 (2), UK: 5 (14), Netherlands: 6 (5), Sweden: 7 (7). 
Figure 6: Fix-line Access Competition

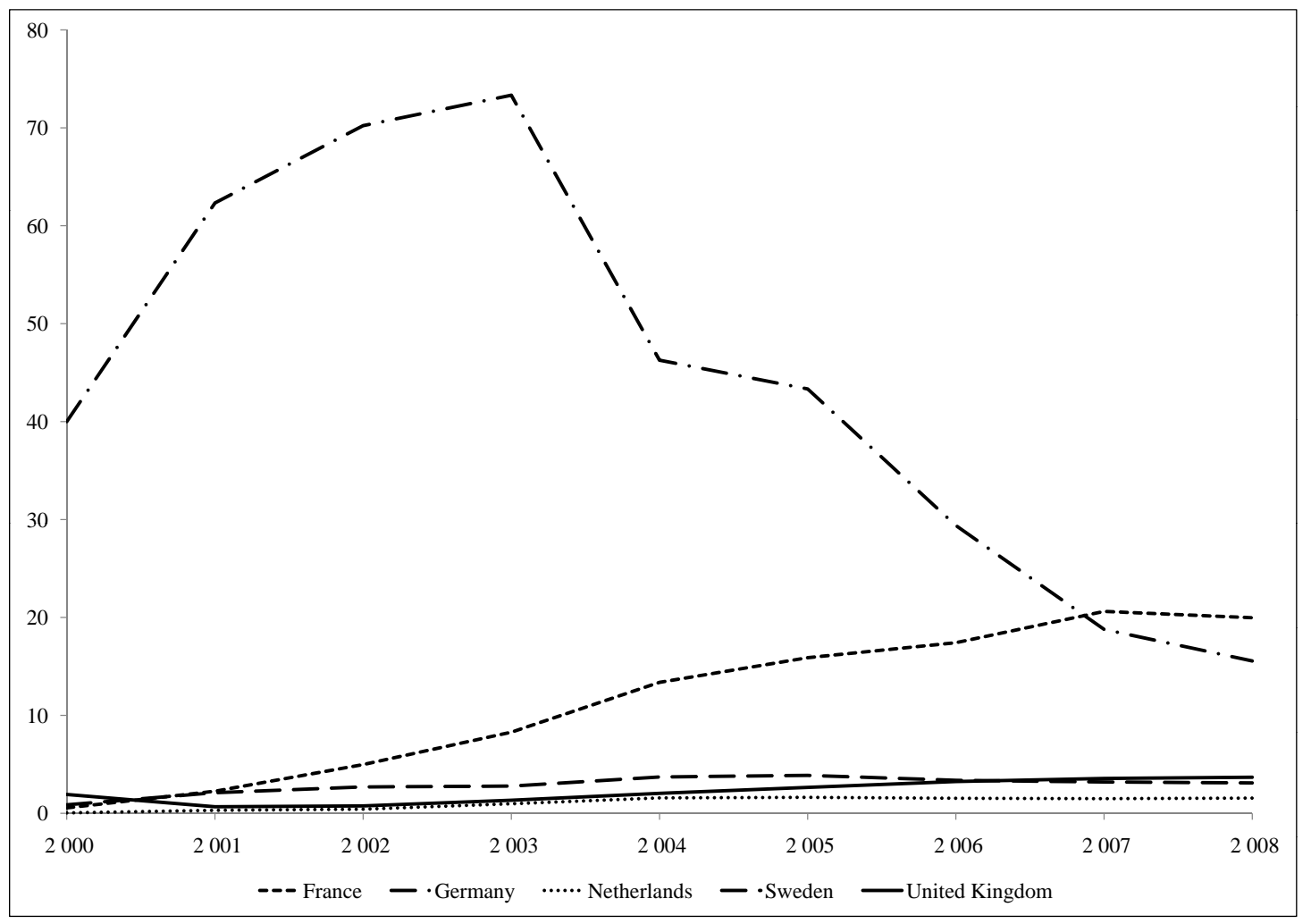

(a) Facility-Based Competition

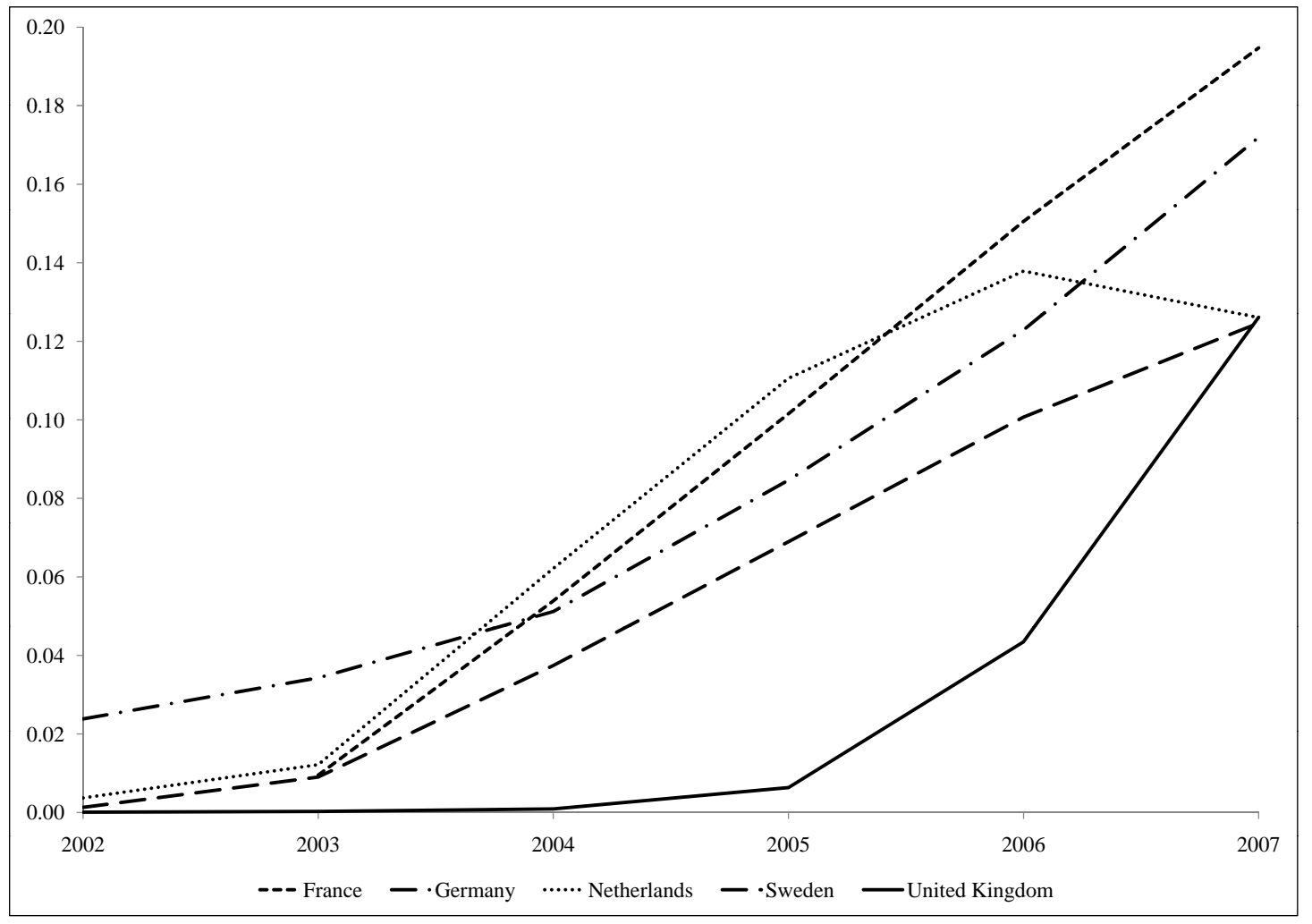

(b) Local Loop Access

Source: Data taken from the OECD Communications Outlook 2009 


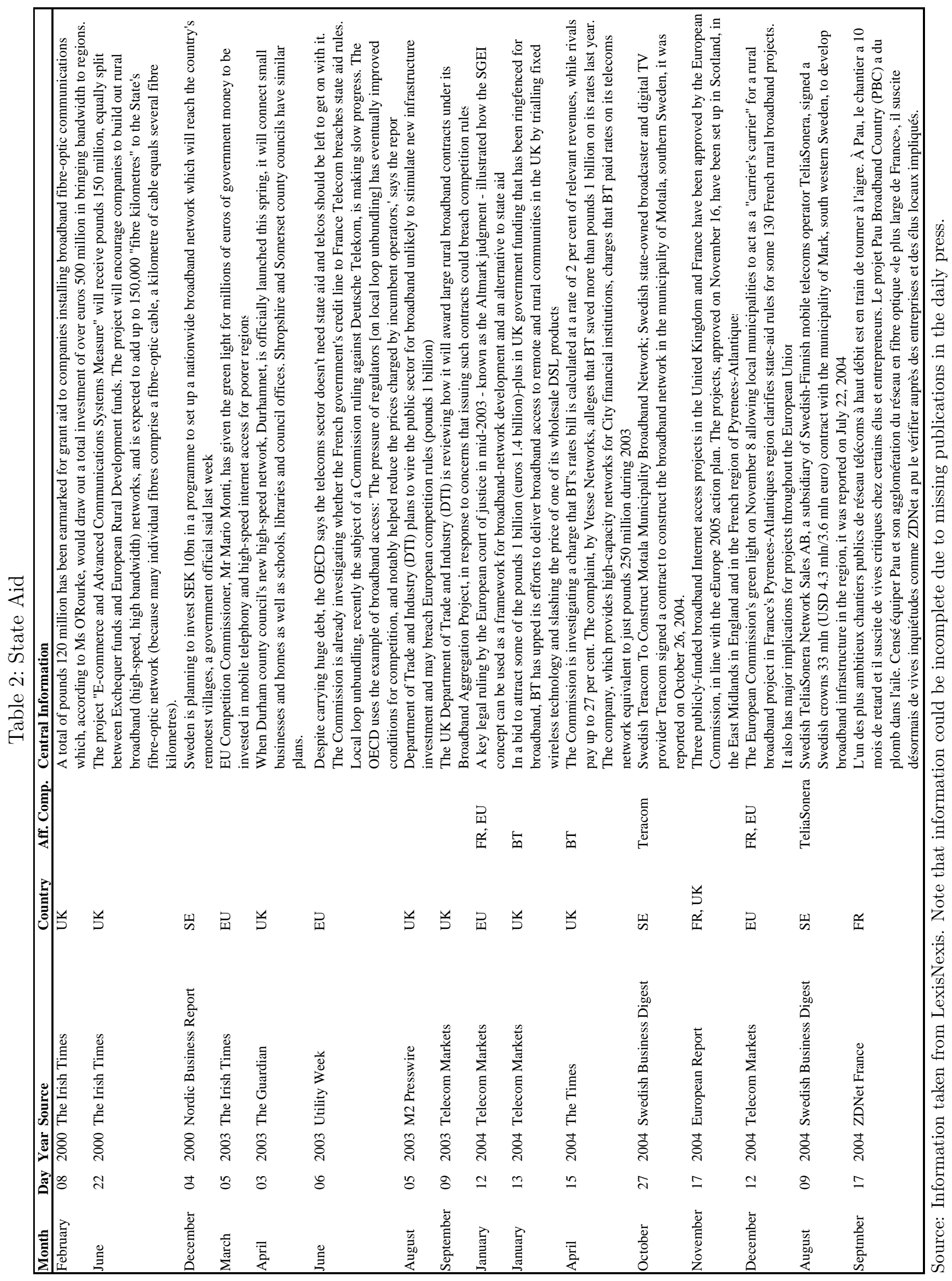




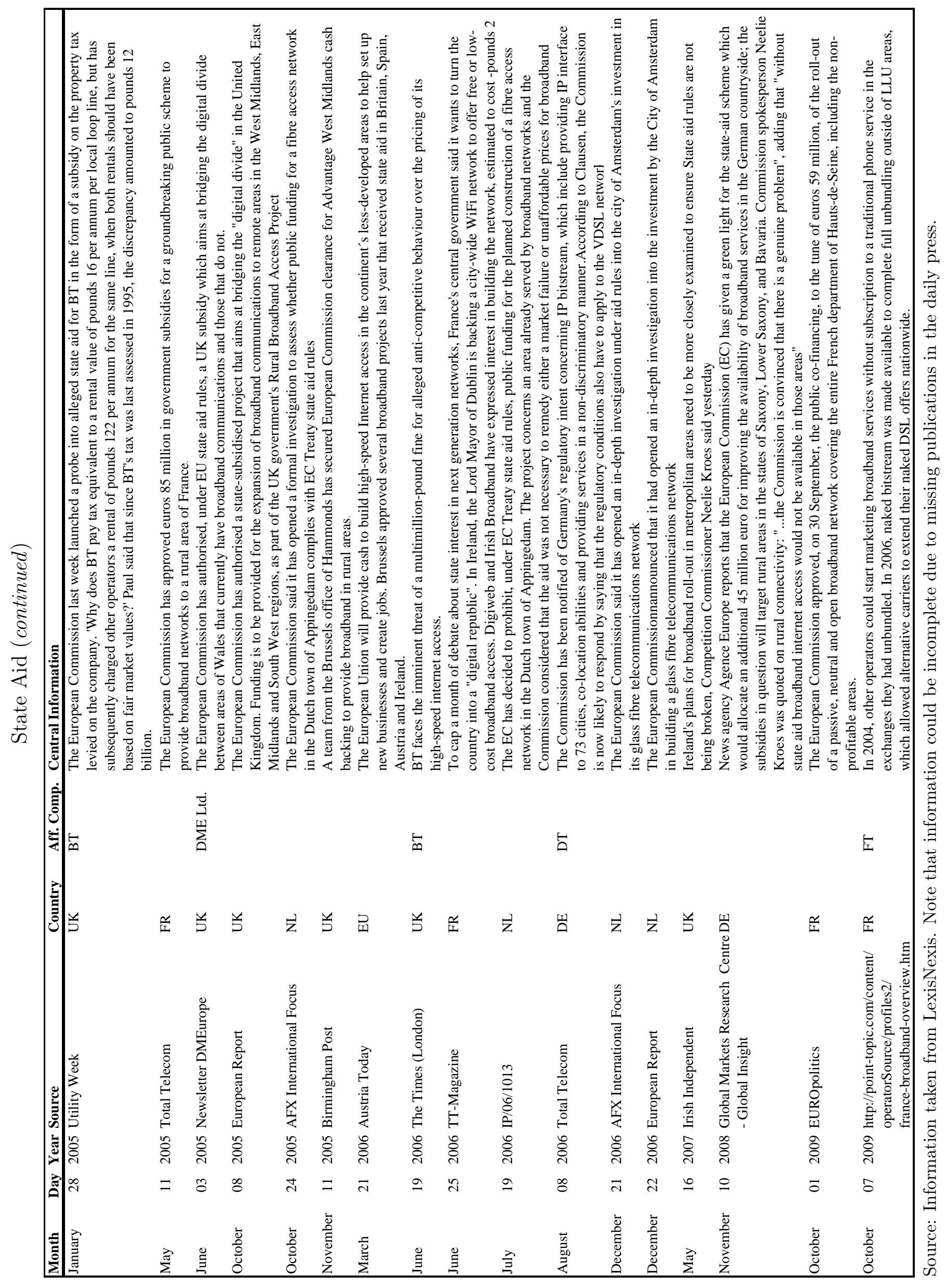




\section{Regulation and Competition - the "Better" Regulatory Package?}

In 2006, the EC started the revision of the Second Regulatory Package based on the second round of market reviews and published its first proposal for adjustments in 2007 for consultations with interested groups. The second proposal was provided in November 2009, turned effective in December 2009 with its publication in the Official Journal of the EU and has to be implemented to national laws by June 2011. The new guidelines mainly rely on the $2002 / 2003$ framework but extend it with a stronger concentration on European-wide integration of telecommunication markets. Therefore, cross-national harmonization of regulation is even more an issue than in the predecessor package.

In this section, I extend the introductory discussion of Section 4 by providing more insights into the issues raised there and continue the consideration to the context of other issues which are not necessarily the central point of consideration of this paper.

The new regulatory package demands transmission service providers to install measures for a minimum level of infrastructure quality for internet services based on existing transmission infrastructure equipment. With regard to consumer rights, the regulatory package requires net neutrality in the sense that higher-quality services must not deter the quality of other services. In line with this issue, consumers have to be informed about the available infrastructure capacity and the "nature of the service to which they are subscribing". ${ }^{27}$ In consequence, consumers have to be informed about traffic management systems and any other limitations which also includes the available (not the maximum) transmission speed.

Besides these changes in contents, attention is given to particular issues which left room for discussions and resulted in comprehensive workload for national courts under the Second Regulatory Framework. The revised rules extend single paragraphs of the 2002/2003 articles in more detail and, thus, reduce the decision space of national governments and regulators. In the following, I consider issues which have been discussed in line with the Second Regulatory Package concerning infrastructure investments and access competition and which change in the new package.

\section{Regulation and the Regulator}

Even before the liberalization, NRAs and the EC have cultivated strong interrelationships to exchange information on current issues with the regulatory implementation on the national level. In line with the the Second Regulatory Package, the EC installed the European Regulators Group (ERG), comprising the heads of the (currently) $27 \mathrm{EU}$ NRAs. This body should exchange information on national market developments and consult the EC with the introduction of new regulatory rules. In contrast to the EC's aim of a common regulatory body, the ERG argues for regulatory sovereignty of national regulators to guarantee the proximity to markets. Thus, the ERG constitutes a counterbalance to the top-down regulation approach fostered by the EC. ${ }^{28}$

\footnotetext{
${ }^{27}$ http://europa.eu/rapid/pressReleasesAction.do?reference=MEMO/09/491\&f ormat= HTML\&aged $=0 \& l$ anguage $=$ EN\&guiLanguage $=$ en

${ }^{28}$ Please see also Chapter 2.
} 
The EC criticizes the role of the ERG as being too weak in the sense that it cannot enforce a consistent application of regulatory rules across all EU member states. Moreover, the EC argues that the magnitude of various national approaches hamper market integration. $^{29}$ Due to the strong national sovereignty of regulators and their integral role in national bureaucratic systems, the EC suspects the ERG not to fulfil its aims of sufficiently consulting the process of pan-European regulation. In 2007, the EC therefore proposed mainly three options to replace the ERG under the new European regulatory system. ${ }^{30}$ The most comprehensive option was the installation of the Single European Regulatory Authority (SERA) as an EU-wide regulator to replace national institutions which has comprehensive decision powers for both national market interventions and also cross-border interventions. A second option was a European regulator with increased decision powers for national implementations of new regulatory rules. However, the role of national regulators would be reduced only weakly. The last option required a better co-ordination of NRAs in the existing framework of the ERG. Due to losing sovereignties in the telecommunication sector, national governments refused all three options. A compromising solution brought forward by the European Parliament in 2009 is the establishment of the BEREC (Body of European Regulators of Electronic Communication). ${ }^{31}$ The BEREC is equipped with more complex regulatory powers than the ERG. In particular, it has veto powers which are similar to the EC to overturn NRA decisions if it suspects national decisions to favor companies with SMP. ${ }^{32}$ While the ERG was a reporting and consulting unit to the EC, the BEREC takes over a supervisory role for NRAs. Although it cannot directly intervene to stop governmental activities restricting NRA decisions, the BEREC has the powers to intervene a posteriori.

However, concerns are raised in two directions on the role of the BEREC: Firstly, while more comprehensive decision powers are given to this new regulatory body in comparison to its predecessor, it is unclear whether existing habits will be changed as its members are those of the ERG and as these members still underly the bureaucratic regimes in their home countries. As the BEREC, i.e. the heads of NRAs, should control their own national regulatory bodies, it is unclear how members will implement this ambiguous task.

Secondly, following the argumentation of the German Monopolies Commission (2009), the installation of the BEREC results in a Co-Regulation Regime which even enhances the existing complexity of regulation as the BEREC has to agree on new national regulatory measures. Thus, while the primary intention with the BEREC was the installation of a more powerful regulatory body to accelerate the pan-European integration process, the decision process on the BEREC has mitigated its powers and makes the regulatory process even more complex and, thus, more in-transparent.

\footnotetext{
${ }^{29}$ http://eur-lex.europa.eu/LexUriServ/LexUriServ.do?uri=COM: 2007 :0699:FIN:EN:PDF, p. 2

${ }^{30}$ http://ec.europa.eu/information_society/policy/ecomm/doc/library/proposals/ia_en. pdf, p. $72 f f$

${ }^{31}$ http://register.consilium.europa.eu/pdf/en/09/st03/st03675-re01.en09.pdf

${ }^{32} \mathrm{~A}$ more detailed description of the BEREC implementation process is provided in Broos et al. (2009).
} 


\section{Market Integration and Fragmentation}

Based on the situation before the liberalization with one monopolist providing countrywide telecommunication services, governments chose also a common country-wide regulation approach. However, since the liberalization, different developments across alternative sub-national markets in all EU member states can be observed, as new entrants focussed on specific regions where they started to provide infrastructure and services. Due to the different status of regions both with regard to technological deployment and with regard to competition, governments and operators chose alternative sub-national strategies to provide infrastructure access. Therefore, the new Regulatory Package also proposes a sub-national market regulation approach as access costs differ across regions, in particular in countries with lower population concentration. Several countries, such as the UK or Austria, already employ sub-national measures to (de)regulate bitstream markets (based on a three-markets classification).

Before regulation could be implemented on a sub-national level, transparent rules had to be established which enable a sub-national market definition and which provide a classification of sub-national competition performance. These rules must be defined on the European level as the Third Regulatory Package proposes sub-national market definitions as a preparation for the pan-European integration. The UK chose sub-national regulation on the level of MDFs as competitors enter regional markets on this level. Following von Weizsäcker (2008), the results of alternative tests for market definitions such as the SSNIP test or the question of collective market dominance support this level of market definition.

An issue raised in sub-national regulation debates is inter-regional subsidization. Following the opponents of sub-national market separations, infrastructure providers use higher profits from urban areas for cross-funding investments in less competitive regions. By separating markets on a sub-national level, competition in more densely-populated areas increases as offers will even better meet customers' characteristics, which reduces profits for cross-funding (Heald, 1997). To overcome this challenge, Knieps (2007) proposes the installation of a universal service fund. Taxes on prices in more densely populated areas are used to cross-fund investments in less lucrative markets where investment projects are auctioned.

In a nutshell, the pan-European integration process requires a complex preparation in advance and cannot be implemented in a one-step approach. As discussed in this subsection, sub-national market separation could accelerate the integration process. As urban areas are much more competitive than rural areas and, thus, could be used to refund investments also in less lucrative regions, it remains to be seen how the integration process is affected by the stage of competition in alternative member states and how national sovereignty affects the process of market definition. 


\section{Functional Separation}

Functional separation (or operational separation) has been discussed already in line with the Second Regulatory Package (Section 3.2). The European Parliament proposes the functional separation of the network unit from the retail and service unit. In contrast to full (ownership) unbundling and legal unbundling, functional separation only requires the separation of units while the vertical organizational structure of a company remains in place. Thus, functional separation should guarantee a non-discriminatory infrastructure access for the integrated company's service unit and for competitors' demanding access (Cave, 2006b; ERG, 2007). Following Article 13a of Directive 2009/140/EC ${ }^{33}$, functional separation complements NRAs' set of instruments and should be implemented if other measures to install competition fail.

However, the EC provides no final definition of functional (i.e. operational) separation and, thus, also provides no information about how to enforce and monitor functional separation and the separated provider. With (perfect) functional separation, the service unit of a vertically integrated operator competes with other operators on the service market, whereas the network operator provides the essential upstream input but does not discriminate between the own unit and competitors either in terms of access prices or in terms of access conditions (Vickers, 1995). Nevertheless, the infrastructure provider has an incentive to affect service competition if this benefits its own unit. With functional separation and even with legal unbundling, a stricter type of separation, a regulator can only partially monitor and intervene on the behavior of the infrastructure operator. While price discrimination could be monitored and enforced under legal unbundling (not under functional separation) (Höffler and Kranz, 2007a; Cremer et al., 2007), non-price discrimination still remains an option for the infrastructure operator (Höfller and Kranz, 2007b; Nikogosian and Veith, 2010).

Following the Special Opinion of the German Monopolies Commission (2009), functional separation could be a valuable instrument at most shortly after the liberalization to foster competition and, therefore, is expectedly no option for governments and NRAs today. Analyses of the Dutch and the Swedish NRAs come to the same result for their national markets after the introduction of functional separation in the UK and in Denmark before 2007. In consequence, functional separation would be an option which affects competition and infrastructure investments if NRAs could monitor and enforce its strict implementation. However, following the examples in various countries and the discussion in the literature, it will not be employed given the current stage of competition, at least in EU-15 telecommunication markets.

The new regulatory framework further promotes the process of pan-European integration by increasing decision powers of pan-European institutions and also by increasing the independence of NRAs on the national level. The installation of the BEREC as a pan-European regulatory body fosters the integration process. However, due to the executive members of the board and their elections by national governments, the impact of this new European regulatory body on the integration process has to be considered with caution.

${ }^{33}$ Directive 2002/21/EC replaces the former Framework Directive (2002/21/EC). 
With regard to the acceleration of the integration process, the EC has proposed to switch from the existing national regulation pattern to sub-national regulation. In doing so, regulation could be reduced or abolished in regions where markets turn to a competitive stage, whereas regulation could be fostered in less competitive markets. Such an approach bears some challenges in advance in particular for larger countries with a lower population concentration. However, from an economic perspective, it enables providers in sub-national markets with higher concentration to negotiate access without further legal obligations, whereas regulators can concentrate on less-competitive markets.

To sum up, the Third Regulatory Package takes up major problems in line with its predecessor. While some pitfalls continue to exist, this new framework enables a further key step to competition and efficiency and, in particular, to the pan-European market integration.

\section{Data and Information Collection}

Data and information for the analysis are collected from multiple sources:

- Data on public ownership (Figure 1) is taken from the OECD Regulatory Index.

- Information on local loop competition and facility-based competition (Figure 6) is provided in the OECD Communications Outlook 2009.

- The EC Implementation Reports provide an overview of national regulation as well as the implementation of EU guidelines and the progress of adoption of the EU Regulatory Packages to national laws. Information on national lawmaking in line with the pan-European steps to market integration (Table 1) is taken from the yearly Implementation Reports since 1997.

- State aid information is collected from the newspaper retrieving system LexisNexis, which provides information based on a keyword search. 